\title{
Storm-driven sediment transport in Massachusetts Bay
}

\author{
John C. Warner ${ }^{\mathrm{a}, *}$, Bradford Butman ${ }^{\mathrm{a}}$, P. Soupy Dalyander ${ }^{\mathrm{b}}$ \\ ${ }^{a}$ U.S. Geological Survey, 384 Woods Hole Road, Woods Hole, MA 02543, USA \\ ${ }^{\mathrm{b}}$ Integrated Statistics, 16 Summer Street, Woods Hole, MA 02543, USA
}

Received 3 November 2006; received in revised form 12 June 2007; accepted 27 August 2007

Available online 22 September 2007

\begin{abstract}
Massachusetts Bay is a semi-enclosed embayment in the western Gulf of Maine about $50 \mathrm{~km}$ wide and $100 \mathrm{~km}$ long. Bottom sediment resuspension is controlled predominately by storm-induced surface waves and transport by the tidal- and wind-driven circulation. Because the Bay is open to the northeast, winds from the northeast ('Northeasters') generate the largest surface waves and are thus the most effective in resuspending sediments. The three-dimensional oceanographic circulation model Regional Ocean Modeling System (ROMS) is used to explore the resuspension, transport, and deposition of sediment caused by Northeasters. The model transports multiple sediment classes and tracks the evolution of a multilevel sediment bed. The surficial sediment characteristics of the bed are coupled to one of several bottom-boundary layer modules that calculate enhanced bottom roughness due to wave-current interaction. The wave field is calculated from the model Simulating WAves Nearshore (SWAN). Two idealized simulations were carried out to explore the effects of Northeasters on the transport and fate of sediments. In one simulation, an initially spatially uniform bed of mixed sediments exposed to a series of Northeasters evolved to a pattern similar to the existing surficial sediment distribution. A second set of simulations explored sediment-transport pathways caused by storms with winds from the northeast quadrant by simulating release of sediment at selected locations. Storms with winds from the north cause transport southward along the western shore of Massachusetts Bay, while storms with winds from the east and southeast drive northerly nearshore flow. The simulations show that Northeasters can effectively transport sediments from Boston Harbor and the area offshore of the harbor to the southeast into Cape Cod Bay and offshore into Stellwagen Basin. This transport pattern is consistent with Boston Harbor as the source of silver found in the surficial sediments of Cape Cod Bay and Stellwagen Basin.
\end{abstract}

Published by Elsevier Ltd.

Keywords: Sediment transport; Three-dimensional numerical model; Storms; Northeasters; Multiple grain sizes; USA; Gulf of Maine; Massachusetts Bay

\section{Introduction}

The transport and fate of particles is important for understanding of a wide range of issues in the coastal ocean, such as the fate of contaminants, delineation of seafloor habitat, and long-term change of the sea floor. Over the last 25 years, observational and modeling studies have identified surface waves, tidal currents, and wind-driven currents as significant processes causing sediment transport on continental shelves (Butman et al., 1979; Drake and Cacchione, 1985; Wright et al., 1994; Cacchione et al., 1999; Harris and Wiberg, 2001; Wiberg et al., 2002). The stress caused by the near-bottom oscillatory currents

\footnotetext{
${ }^{*}$ Corresponding author. Tel.: + 15084572237 ; fax: +15084572310 .

E-mail address: jcwarner@usgs.gov (J.C. Warner).
}

associated with surface waves (Grant and Madsen, 1979) cause sediment resuspension, while advection by winddriven, density-driven, and/or tidal currents cause net transport. In areas of complex coastline, topography, and sediment characteristics, understanding of long-term sediment fate is difficult with observations alone. Numerical sediment transport modeling provides the capability to examine idealized case studies and realistic scenarios to explore the contributions of various processes with detailed spatial and temporal resolution. Shelf sediment-transport models have been applied in two dimensions (cross shelf and depth) (Zhang et al., 1999; Cookman and Flemings, 2001; Harris and Wiberg, 2001, 2002; Davies and Xing, 2002), in three dimensions with idealized (Kampf and Fohrmann, 2000) and realistic environments (Holt and James, 1999; Signell and Harris, 2000; Luff and Moll, 
2004), and with particle tracking algorithms (Kourafalou et al., 2004). Often the simulations are limited to a single sediment class, typically use only a single-layer bed, and lack adequate observational data for model verification.

Massachusetts Bay is a semi-enclosed embayment in the western Gulf of Maine about $50 \mathrm{~km}$ wide and $100 \mathrm{~km}$ long. Sediment resuspension is controlled predominately by storm-induced surface waves and transport by the tidaland wind-driven circulation. Previous observational studies in Massachusetts Bay (Geyer et al., 1992; Beardsley et al., 1997; Butman et al., 2004a, 2006) identify circulation patterns, provide long-term observations at selected locations, and identify the importance of storms to bottom sediment resuspension. Previous numerical modeling studies including the Gulf of Maine have addressed tidal- and storm-driven currents (Greenberg, 1983; Wright et al., 1986; Lynch and Naimie, 1993; Signell et al., 1994; Lynch et al., 1996; Larmusiaux, 2001; Chen et al., 2003; Fan et al., 2005; He et al., 2005; Hetland and Signell, in press), the transport of salinity, temperature and suspended matter (Signell et al., 2000; Jiang and Zhou, 2003), water quality (Jiang and Zhou, 2003), and the dilution of sewage effluent (Signell et al., 1996). Other modeling efforts predict the effects of enhanced bottom stress due to waves (Signell and List, 1997). Butman and Bothner (1998) identified Stellwagen Basin and Cape Cod Bay as long-term sinks for finegrained sediments and presented a conceptual model suggesting that northeast storms are a principal mechanism responsible for transporting sediments to these locations using silver that is introduced into Boston Harbor in sewage effluent as a tracer.

We are developing a coupled wave, circulation, and sediment-transport model. The model previously has been tested against several analytical solutions for steady uniform flow, and applied in an idealized estuary. These tests show that the model predicts the correct vertical Rouse profiles of sediment concentration in steady, uniform openchannel flows, and produces the expected development of a turbidity maximum in the idealized estuary (Warner et al., 2005). In realistic settings the model has been shown to qualitatively predict the correct behavior for sediment transport in the Adriatic Sea (Sherwood et al., 2004; Harris et al., submitted) and on the southern California continental shelf (Blaas et al., 2007).

In this paper we use the model to explore the effects of storms on the transport and long-term fate of sediments in Massachusetts Bay. We compare wave model results to wave observations during selected northeast storms, and circulation model results to tidal and current observations. Observations of sediment movement in Massachusetts Bay identify storms with winds from the northeast (hereafter Northeasters) as a major contributor to resuspension of bottom sediments (Bothner et al., 2002; Butman and Bothner, 1998). Wave buoy data for the period 1990-2006 are used to characterize the intensity of the Northeasters and to identify the largest storms during this period. One numerical simulation explores how a mixed bed of sediments of varying sizes would evolve under a series of Northeasters. A second set of simulations explores the pathways and fate of sediments caused by Northeasters with winds from different directions. These simulations are the first to explore the role of storms in the transport and long-term fate of sediments in Massachusetts Bay using a three-dimensional coupled wave-circulation-sediment transport model.

\section{Geologic and oceanographic setting}

Massachusetts Bay extends from Cape Ann southward along the eastern coast of Massachusetts (Fig. 1). The Bay is open to the Gulf of Maine along the eastern boundary between Cape Ann and Cape Cod, but the opening is partly blocked by Stellwagen Bank, a shallow bank that rises to within $20 \mathrm{~m}$ of sea surface at its southern end. Stellwagen Basin, located to the west of Stellwagen Bank, is the deepest part of Massachusetts Bay with maximum water depth of $95 \mathrm{~m}$. Cape Cod Bay is located between Cape Cod and the eastern coast of Massachusetts; the deepest water of Cape Cod Bay is $40 \mathrm{~m}$ at its center.

The distribution of surficial sediment in Massachusetts Bay reflects the topography, the processes that resuspend and transport sediments, and the geologic history of the region (Butman et al., 2004b, 2006). Stellwagen Bank and Jeffreys Ledge are shallow banks (20-40 m water depth) covered with sand and gravel that have been winnowed by waves and currents since the last rise in sea level. Similarly, the inner shelf along the western shore of Massachusetts Bay at water depths shallower than $40-50 \mathrm{~m}$ is covered with sand, gravel and rock. Stellwagen Basin, the deepest part of Massachusetts Bay, is $80-90 \mathrm{~m}$ deep and is floored with fine-grained mud; the basin is generally considered to be a tranquil long-term depositional site for sediments winnowed from the inshore areas and the shallow banks. Sediment accumulation rates are about $0.001 \mathrm{~m}$ year $^{-1}$ (Crusius et al., 2004). An area of coarser sediments in the southern portion of Stellwagen Basin at about $70 \mathrm{~m}$ water depth separates the fine sediments in central Cape Cod Bay and northern Stellwagen Basin.

Currents can conceptually be separated into a residual current, low-frequency currents caused by winds and river runoff, and tidal currents. The Gulf of Maine Coastal Current flows to the southeast at $5-10 \mathrm{~cm} \mathrm{~s}^{-1}$ to the east of Stellwagen Bank (Geyer et al., 1992). Some of this flow enters Massachusetts Bay south of Cape Ann and exits at Race Point Channel (Fig. 1). This inflow is variable and the strength is typically $1-3 \mathrm{~cm} \mathrm{~s}^{-1}$ driving a weak counterclockwise circulation in Massachusetts Bay (Geyer et al., 1992). In spring, local river runoff through Boston Harbor and from rivers along the Maine coast to the north cause low-frequency fluctuations in the residual circulation (Butman, 1976; Geyer et al., 1992). The tidal range in Massachusetts Bay is about $2 \mathrm{~m}$. Tidal currents are dominated by the semi-diurnal tide $\left(\mathrm{M}_{2}\right)$. The phase and amplitude of the tidal elevation is nearly uniform 


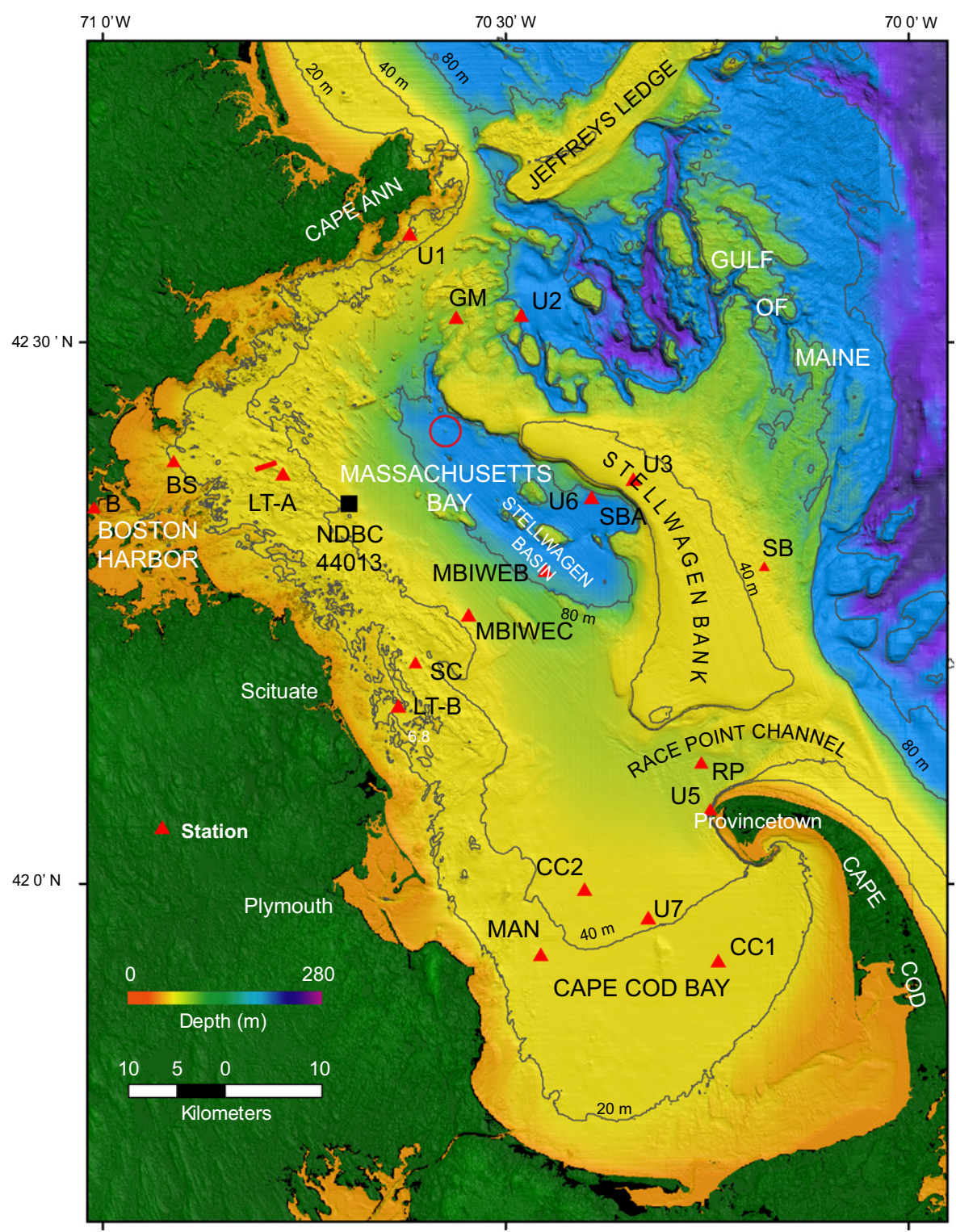

Fig. 1. Massachusetts Bay, located in the western Gulf of Maine, is open to the Gulf along the northeastern boundary. In contrast, Cape Cod Bay is sheltered from the northeast by Cape Cod. The new Boston ocean outfall (indicated with a red line) is located in western Massachusetts Bay in about $35 \mathrm{~m}$ water depth, and the Massachusetts Bay Disposal Site (red circle) in Stellwagen Basin in about $80 \mathrm{~m}$ water depth. Current monitoring stations are indicated with red triangles (Table 1). In winter, the Gulf of Maine coastal current flows southeastward across the mouth of Massachusetts Bay; a weak flow enters Massachusetts Bay south of Cape Ann, flows southeastward to Cape Cod Bay, and exits north of Race Point.

throughout the bay. Tidal currents are largely bi-directional (east-west) and flow into and out of the bay; the magnitude of tidal currents are strongest in the Race Point Channel, across Stellwagen Bank, and in the approaches to Boston Harbor. The water column in Massachusetts Bay exhibits seasonal stratification caused by seasonal heating and cooling along with spring river runoff. In the summer months the Bay is strongly stratified with the pycnocline typically found at 15-20 m depth (Geyer et al., 1992). During the winter (November-March) Massachusetts Bay is typically well-mixed (Signell et al., 1994).

An understanding of the transport and fate of particles is important to assess the effects of anthropogenic activities in Massachusetts Bay. In 1985, the Massachusetts Water
Resources Authority (MWRA) was established to clean up pollution in Boston Harbor resulting from the long-term discharge of untreated sludge and sewage effluent into the Harbor. Elimination of the discharge of sewage sludge, addition of secondary treatment, and moving the discharge of treated effluent to a new ocean outfall 9.5 miles offshore in Massachusetts Bay (in deeper water and away from the coast) has resulted in improved the water quality in Boston Harbor and no apparent change in Massachusetts Bay, as predicted (Signell et al., 2000). Although the loading of solids and metals through the new outfall is reduced by a factor of 4 and 6 since 1990, respectively (Werme and Hunt, 2003), it is of interest to conceptually compare the long-term fate of particles introduced into Boston Harbor 
with particles introduced into western Massachusetts Bay at the site of the new outfall. The Massachusetts Bay Disposal Site (MBDS), located in Stellwagen Basin (Fig. 1), has historically been used for the disposal of wastes from the Boston metropolitan region, and is still used for the disposal of dredged material. Because of the relatively deep water $(80 \mathrm{~m})$ and fine sediments at this site, the MBDS is thought to be a depositional location where material will remain sequestered for the long-term.

The metal silver, introduced from the photo-processing industry, is an ideal tracer for sewage effluent because of low natural background concentrations. Concentrations of silver in the surficial sediments are highest in Boston Harbor (in excess of $4 \mathrm{ppm}$ in some areas) and decrease offshore to background concentrations of $0.14-0.18 \mathrm{ppm}$ to the east of Stellwagen Bank in the Gulf of Maine (Ravizza and Bothner, 1996). The distribution of silver in the surface sediments reflects loadings and transport processes occurring over the last 100 years. Immediately offshore of Boston, silver concentrations of $0.7 \mathrm{ppm}$ are found in small areas of fine-grained sediments. Silver concentrations are about $0.5 \mathrm{ppm}$ in Cape Cod Bay and $0.20-0.26 \mathrm{ppm}$ in Stellwagen Basin, suggesting alongshore and offshore transport to these depositional sites from the Boston source.

\section{Methods}

The analysis and numerical methods require data of observed winds, waves, sea level, currents, and sediment distribution on the sea floor. This information is used to drive the numerical model, compare the model results to assess the model predictions, and to determine a stormranking index.

\subsection{Observations}

\subsubsection{Wind, surface waves, sea level and current}

Wind and wave data were obtained from the National Data Buoy Center (NDBC) Station 44013 located in Massachusetts Bay. Between 1990 and 1993, the observations were from a Large Navigational Buoy at $42^{\circ} 22.8^{\prime} \mathrm{N}$, $70^{\circ} 46.8^{\prime} \mathrm{W}$ at about $30 \mathrm{~m}$ water depth. From 1993 through 2006 , the platform was a $3-\mathrm{m}$ discus buoy located in $55 \mathrm{~m}$ of water at $42^{\circ} 21.23^{\prime} \mathrm{N}, 70^{\circ} 41.48^{\prime} \mathrm{W}$ (Fig. 1). Wind speed and direction data are acquired over $8 \mathrm{~min}$ sampling intervals every hour. Statistical parameters of significant wave height, peak and mean wave period are calculated by the NDBC from 20 min of continuous wave spectral data, recorded every hour.

Current, bottom pressure, and sea-level data in Massachusetts Bay that are used to compare with the model were obtained from a variety of sources, including the Massachusetts Bays Program study (Geyer et al., 1992), a USGSMWRA long-term study (Butman et al., 2004a), the National Ocean Service, the Gulf of Maine Observing System (GoMOOS), and USGS data archives (Table 1 and
Fig. 1). Currents were measured with a variety of instruments and sampling schemes, including Vector Measuring Current Meters (VMCM), electromagnetic S4 current meters, and Acoustic Doppler Current Profilers (ADCP). Most data records were 1-6 months long, with the exception of those at LT-A, LT-B, and GoMOOS A where data records are 12, 5, and 4 years long, respectively. Tidal constituents for elevation and current were obtained from publications, or carried out using T_TIDE (Pawlowicz et al., 2002). The tidal constituents for elevation and current are tabulated in Appendix A.

\subsubsection{Surficial sediment distribution}

Surficial sediment texture data for Massachusetts Bay were obtained from a compilation of texture samples for the Gulf of Maine (Poppe et al., 2003). This data set is a compilation of surficial sediment data of grain size and lithology for over 47,000 stations off the northeastern US The data in the region of study (Fig. 1), about 5300 samples, were gridded and contoured to provide an overview of the surficial sediment texture. There are only a few sediment samples along the western shore of Massachusetts Bay where the rocky sea floor precludes obtaining samples with a grab sampler.

\subsection{Storm index}

The NDBC wave data were used to characterize the strength and duration of storms based on bottom stress caused by wave-driven currents. Near-bottom wave-orbital velocities at $30-\mathrm{m}$ water depth were calculated from significant wave height and dominant wave period following the method of Wiberg and Sherwood (in press) using the Donelan spectral formulation. Bottom stress $\left(\rho u_{w}^{* 2}\right)$ was then calculated from linear wave theory following Madsen (1994). An approximate $u_{\text {critical }}^{*}$ for resuspension of finegrained sediments is $0.01 \mathrm{~m} \mathrm{~s}^{-1}$ or a stress of $0.1 \mathrm{~Pa}$. Storms were defined as periods when $u_{w}^{*}$ exceeded $u_{c r i t i c a l}^{*}$ for at least $6 \mathrm{~h}\left(u_{w}^{*}\right.$ must fall below $u_{\text {critical }}^{*}$ for at least $12 \mathrm{~h}$ for a new storm to be defined). The integrated excess wave stress at $30 \mathrm{~m}$ water depth $\left(\operatorname{IES}_{30}\right)$, a measure of the strength of storms in eroding bottom sediments, was calculated as the sum of $\left(u_{w}^{* 2}-u_{\text {critical }}^{* 2}\right)$ when $u_{w}^{*}>0.01 \mathrm{~m} \mathrm{~s}^{-1}$ during each storm. Storms were ranked by IES $_{30}$. The IES was calculated at $30 \mathrm{~m}$, a depth where the sea floor is not affected by relatively short-period waves and a representative water depth for Massachusetts Bay; the choice of a different resuspension threshold or depth affects the number and duration of storms but does not alter the ranking of the largest events or their characteristics.

\subsection{Numerical models}

A coupled surface wave, hydrodynamic, and sediment transport model is used in this paper to investigate sediment transport in Massachusetts Bay. The characteristics of each model are described below. 
Table 1

Observations used to compare observed tidal elevation and current to model simulations

\begin{tabular}{|c|c|c|c|c|c|c|c|}
\hline Station location & Site name & $\begin{array}{l}\text { Organization } \\
\text { (experiment) }\end{array}$ & $\begin{array}{l}\text { Water depth } \\
\text { (m) }\end{array}$ & Latitude & Longitude & $\begin{array}{l}\text { Current (depth } \\
\text { below surface) (m) }\end{array}$ & $\begin{array}{l}\text { Pressure } \\
(\mathrm{m})\end{array}$ \\
\hline Mass Bay ${ }^{\mathrm{a}}$ & 44013 & NDBC & 55 & 42.3533 & -70.6917 & - & - \\
\hline Boston (NOS 8443970) & B & NOS & 6 & 42.3580 & -71.0470 & - & 0 \\
\hline Mass Bay & LT-A & USGS (MWRA) & 33 & 42.3767 & -70.7833 & 5,23 & 31 \\
\hline Scituate & LT-B & USGS (MWRA) & 21 & 42.1633 & -70.6400 & 5,7 & 20 \\
\hline Gloucester & $\mathrm{U} 1$ & UNH (MBC) & 5 & 42.5967 & -70.6260 & - & 3 \\
\hline North Channel & $\mathrm{U} 2$ & UNH (MBC) & 70 & 42.5223 & -70.4877 & $4,25,60$ & - \\
\hline Stellwagen Bank & U3 & UNH (MBC) & 29 & 42.3718 & -70.3483 & 4,25 & 25 \\
\hline Provincetown & U5 & UNH (MBC) & 5 & 42.0617 & -70.2433 & - & 3 \\
\hline Stellwagen Basin & U6 & UNH (MBC) & 87 & 42.3552 & -70.4002 & 4 & \\
\hline Stellwagen Basin & U6 (SBA) & USGS (MBC) & 85 & 42.3550 & -70.4005 & 84 & 84 \\
\hline Stellwagen Basin & U6 (SBB) & USGS (MBC) & 87 & 42.3573 & -70.3997 & 77 & - \\
\hline Cape Cod Bay & U7 & UNH (MBC) & 39 & 41.9670 & -70.3330 & 4,25 & - \\
\hline Broad Sound & BS & WHOI (MBC) & 20 & 42.3867 & -70.9083 & 5,18 & - \\
\hline Scituate & $\mathrm{SC}$ & WHOI (MBC) & 25 & 42.2033 & -70.6167 & 5,23 & - \\
\hline Manomet Point & MAN & USGS (MBC) & 36 & 41.9317 & -70.4600 & 5,26 & - \\
\hline Race Point & RP & USGS (MBC) & 60 & 42.1067 & -70.2467 & $5,25,50,59$ & - \\
\hline Cape Cod Bay (1) & $\mathrm{CC} 1$ & USGS (archive) & 30 & 41.9280 & -70.2430 & 29 & 29 \\
\hline Cape Cod Bay (2) & $\mathrm{CC} 2$ & USGS (archive) & 47 & 41.9942 & -70.4093 & $6,24,40,46$ & 46 \\
\hline Stellwagen Bank & SBnk & USGS (archive) & 54 & 42.2935 & -70.1830 & $5,31,48$ & - \\
\hline Stellwagen Basin & MBIWEB & USGS (MBIWE) & 85 & 42.2881 & -70.4575 & - & 83 \\
\hline Stellwagen Basin & MBIWEC & USGS (MBIWE) & 50 & 42.2470 & -70.5529 & - & 49 \\
\hline Cape Ann & GM & GoMOOS & 65 & 42.5232 & -70.5683 & 2,3 & - \\
\hline
\end{tabular}

Organizations: National Data Buoy Center (NDBC), National Ocean Survey (NOS), U.S. Geological Survey (USGS), University of New Hampshire (UNH), Woods Hole Oceanographic Institution (WHOI), Massachusetts Water Resources Authority (MWRA). Experiments: Massachusetts Bay Circulation Experiment (MBC); Massachusetts Bay Internal Wave Experiment (MBIWE); USGS/MWRA Long-term observations (MWRA).

${ }^{\mathrm{a}}$ Wind measured at this site, elevation $5 \mathrm{~m}$.

\subsubsection{Waves $(S W A N)$}

Simulating WAves Nearshore (SWAN v40.41AB) is a spectral wave model that solves the spectral density evolution equation (Booij et al., 1999). A horizontal curvilinear grid for almost the entire length of the Gulf of Maine was constructed consisting of $100 \times 200$ cells (Fig. 2). This grid provided a horizontal resolution on the order of $600 \mathrm{~m}$ near the coast in Massachusetts Bay to nearly $6000 \mathrm{~m}$ along the northern extent. The grid was not extended farther to the south because most storms that affect Massachusetts Bay have winds from the North or North-East. The grid was extended across the Gulf of Maine to provide adequate spatial distance for wave growth, eliminating the need for open boundary information.

\subsubsection{Hydrodynamics (ROMS)}

The hydrodynamic numerical circulation model is Regional Ocean Modeling System (ROMS v2.2). ROMS is a free-surface, hydrostatic, finite-difference model with orthogonal curvilinear coordinates in the horizontal, and stretched terrain following coordinates in the vertical (Haidvogel et al., 2000; Chassignet et al., 2000; Shchepetkin and McWilliams, 2005). ROMS is an opensource, freely available model that features several advection schemes, boundary conditions, turbulence closures, and is computationally efficient on both single- and multiprocessor computers.
The horizontal curvilinear grid used for ROMS was a subset of the wave grid and consists of $100 \times 135$ cells, extending almost midway into the Gulf of Maine (Fig. 2). The full grid was not used for the hydrodynamics for computational efficiency. In the vertical, the grid was discretized with 20 terrain-following (sigma) levels providing resolution between 0.15 and $15 \mathrm{~m}$. At the eastern and northern open boundaries the elevation was prescribed from the $\mathrm{M}_{2}, \mathrm{~S}_{2}, \mathrm{~N}_{2}, \mathrm{~K}_{2}, \mathrm{O}_{1}, \mathrm{~K}_{1}$, and $\mathrm{Q}_{1}$ harmonic components from the tidally driven ADCIRC model (Leuttich et al., 1992) that produced the 2001 tidal database (Mukai et al., 2001) of water level and current velocity phases and amplitudes for the Northern Atlantic region. These represent the principal lunar semidiurnal, principal solar semidiurnal, lunar elliptic semidiurnal, principal lunar diurnal, and lunisolar diurnal tides, respectively. Salinity and temperature are held constant at $S_{0}=35 \mathrm{ppt}$ and $T_{0}=10^{\circ} \mathrm{C}$ to simulate the well-mixed winter conditions. Subgrid scale parameterizations for the mixing of momentum and scalars are accomplished with the Generic Length Scale two-equation turbulence closure (Umlauf and Burchard, 2003) parameterized as the $k-\omega$ model. The implementation of this closure into ROMS is discussed in detail by Warner et al., (2005).

\subsubsection{Sediment transport (ROMS)}

Algorithms to simulate the advective-diffusive transport of suspended sediment in the water column were added to 


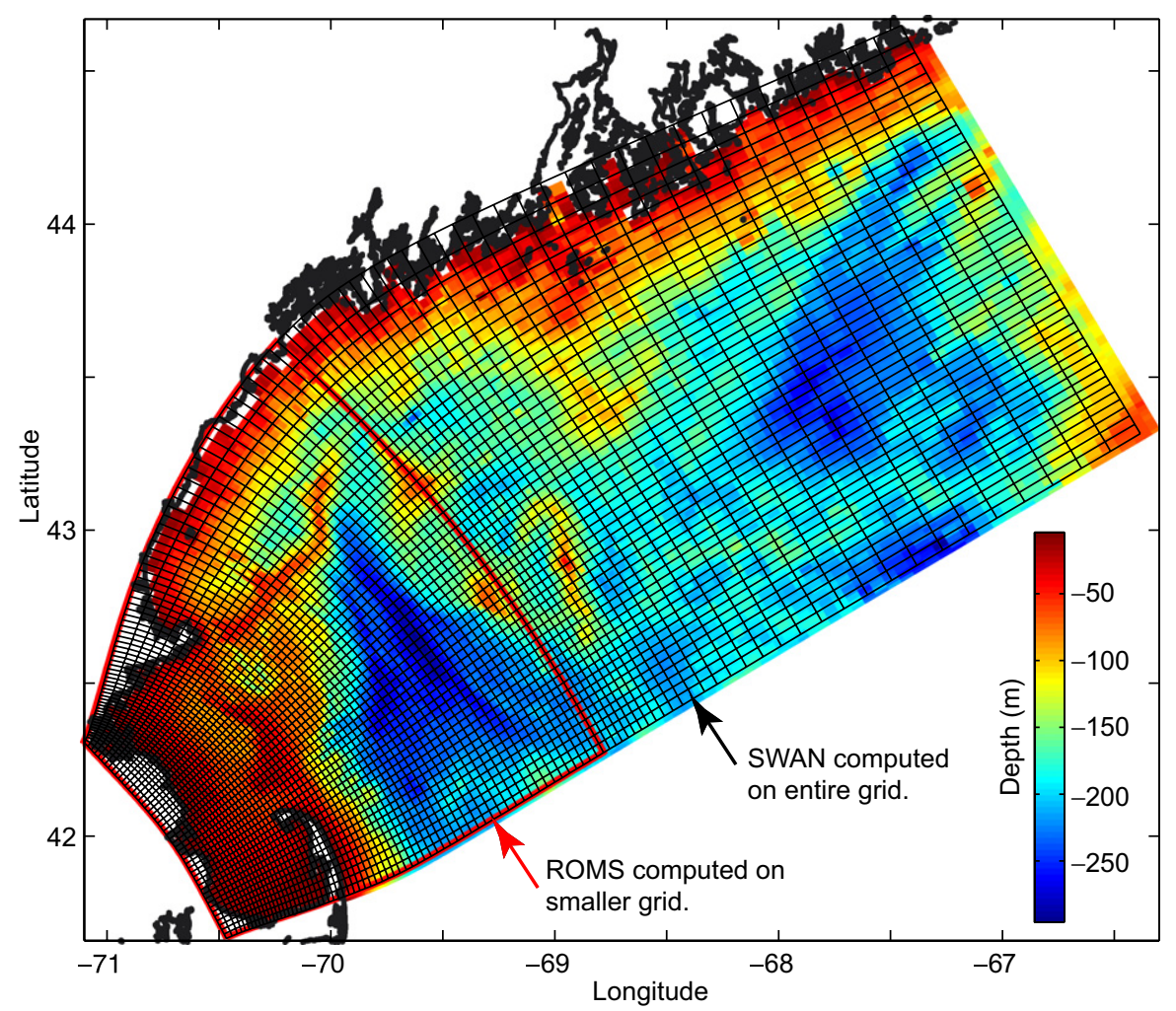

Fig. 2. Grids used for numerical simulations of waves, currents, and sediment transport in Massachusetts Bay (every other grid line shown). A $100 \times 200$ mesh grid, extending across the entire Gulf of Maine, was used for SWAN wave modeling. A $100 \times 135$ mesh subset of this grid was used for ROMS hydrodynamic and sediment transport modeling.

the ROMS model (Warner et al., in press). The model transports an unlimited number of user-defined sediment classes. Each class has attributes of grain diameter, density, settling velocity, critical stress threshold for erosion, and erosion rate. Erosion and deposition algorithms control mass balance between suspended sediment in the water column and the evolution of the multi-level bed. Exchange of sediment mass between the bed and the water column occurs through erosive and depositional fluxes at each model time step. Currently the model does not distinguish between cohesive and non-cohesive sediment classes and sediment erosion is based on the suspended sediment flux formulation (Ariathurai and Arulanandan, 1978):

$E_{s, m} E_{0, m}(1-\phi) \frac{\tau_{w}-\tau_{c e, m}}{\tau_{c e, m}}$ when $\tau_{w}>\tau_{c e}$,

where $E_{s}$ is the surface erosion mass flux $\left(\mathrm{kg} \mathrm{m}^{-2} \mathrm{~s}^{-1}\right), E_{0}$ is a bed erodibility constant $\left(\mathrm{kg} \mathrm{m}^{-2} \mathrm{~s}^{-1}\right), \varphi$ is the porosity (volume of voids/total volume) of the top bed layer, $\tau_{c e}$ is the critical shear stress for erosion, the subscript $m$ is for each sediment class, and $\tau_{w}$ is the combined maximum wave and current interaction shear stress. Sediment resuspension is multiplied by the fraction of each sediment class and is limited by the availability of sediment for each class in the active layer (described below).

The bed is a three-dimensional framework that underlies the hydrodynamic mesh. The bed consists of a user specified number of layers, which remains fixed for the simulation. For each cell in each layer, the user defines an initial thickness, the fraction of each sediment class in each cell, sediment porosity, and age. Calculation of sediment mass in each bed layer is based on the provided information. In addition to the bed framework, additional specific properties of the bed surface are calculated: mean grain diameter, density, settling velocity, critical stress for erosion, active layer thickness, ripple height, and ripple wavelength.

At the beginning of each time step, an active layer thickness is calculated. This thickness represents a surficial layer that is well-mixed and available for mobilization. The active layer is computed from the relation of Harris and Wiberg (1997):

$z_{\text {iactv }}=k_{1}\left(\tau_{w}-\overline{\tau_{c e}}\right)+k_{2} \overline{D_{50}}$,

where $z_{\text {iact }}$ is the (non-zero) active layer thickness, $\overline{\tau_{c e}}$ is the mean critical stress for erosion of surficial sediment, $\overline{D_{50}}$ is the mean grain diameter of surficial sediment, and $k_{1}$ and $k_{2}$ are empirical constants with values of 7.0 and 6 , respectively. The thickness of the top bed layer has a minimum thickness equivalent to $z_{\text {iactv }}$. If the top layer is thicker than $z_{\text {iact }}$, no action is required. If the top layer is less than $z_{\text {iact }}$ thick, then the top layer thickness is increased by entraining sediment mass from deeper layers until the top layer thickness equals $z_{\text {iactv }}$. If sediment from deeper than the second layer is mixed into the top layer 
then the bottom layer is split to enforce a constant number of layers.

Each sediment class is transported via the solution to the advection-diffusion equation. Bed interaction terms exchange masses of sediment between the water column and the top bed layer. For erosion, the sediment is removed from the top layer using the calculated erosive flux (Eq. (1)) but limited to the availability of that sediment class in the active layer. For deposition, the sediment is added to the top bed layer. If sediment continues to deposit in the top layer, then a new layer is formed (based on user-defined time or thickness). If a new layer is created, then the bottom 2 layers are combined to ensure that the total number of vertical bed layers stays constant. After the erosion and deposition, the active layer thickness is again calculated and newly deposited material is mixed into the top layer. If deposition continues, then the area typically will yield a thin active layer thickness, so eventually a new layer will form and not be remixed into the top layer. Finally, the surficial sediment characteristics are calculated from the sediment characteristics of the top layer.

The bottom boundary layer routine then utilizes the surficial sediment properties along with information of the wave field of bottom orbital velocity, wave period, and wave direction to output enhanced bottom stress for the currents, estimates of the maximum combined wave current stress for sediment transport, and bottom characteristics of ripple height and wavelength. The stresses are then passed to the hydrodynamic routines and then to the sediment routines to complete the feedback through time (Warner et al., in press).

\section{Results}

\subsection{Sediment resuspension and storm frequency}

Observational and modeling studies in Massachusetts Bay have identified the combined stress caused by waves and currents as the most important process causing sediment resuspension. Tidal currents, wind-driven currents, or currents associated with the spring runoff are typically not strong enough alone to resuspend sediments. The stresses caused by the near-bottom oscillatory currents associated with surface waves cause suspension of sediment. The sediment is then advected by wind-driven, density-driven, and/or tidal currents. The largest waves in Massachusetts Bay are associated with winds from the northeast (Fig. 3) because of the unobstructed fetch from the Gulf of Maine. The long-term observations at LT-A show that storms with large surface waves, are a key factor that causes sediment resuspension in Massachusetts Bay (Fig. 4). These storms typically occur in the fall or winter when the water column is well-mixed. The percentage of time this threshold is exceeded decreases exponentially with increasing water depth and is less than a few percent of the time in water deeper than $50 \mathrm{~m}$. At any given depth, resuspension is more frequent in winter than in summer.

The resuspension, transport, and long-term fate of particles in Massachusetts Bay is the cumulative result of the transport by numerous storms with winds and waves from various directions, but dominated by the transport during storms with winds from the northeast (Northeast storms) and the large associated waves. NDBC wave data from January 1990 through December 2006 were used to examine storm frequency and magnitude based on the strength of near-bottom stress $\left(\mathrm{IES}_{30}\right)$ associated with waves at $30 \mathrm{~m}$ water depth. For the 17 -year period, there were 380 storms covering about $13 \%$ of the total time. The average length of a storm was $47 \mathrm{~h}$; the average length of the 10 strongest storms was $130 \mathrm{~h}$. The long duration of the larger storms most likely reflects waves generated in the Gulf of Maine that propagate into Massachusetts Bay. The ten strongest storms, ranked by IES $_{30}$, comprised about $7 \%$ of the storm time and less than $1 \%$ of the total time (Table 2, Fig. 5). The direction of the vector-averaged wind
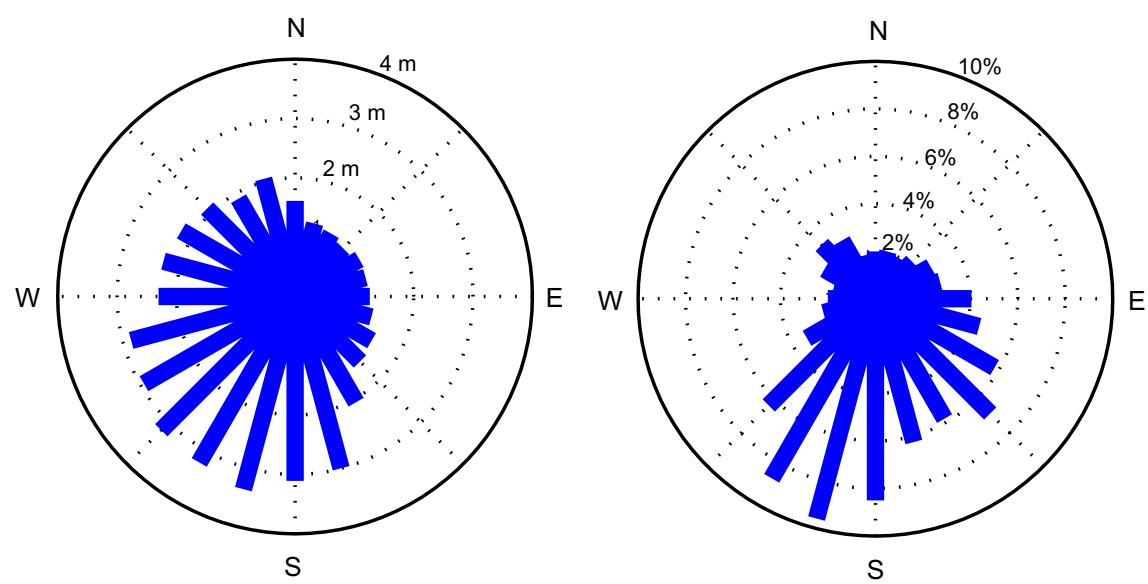

Fig. 3. Mean significant wave height (left) as a function of wind direction for winds greater than $0.2 \mathrm{~Pa}$ and percentage of $u^{*}$ wave greater than $0.01 \mathrm{~m} \mathrm{~s}{ }^{-1}$ at $30 \mathrm{~m}$ water depth as a function of wind direction (right). The wind blows toward the direction indicated. Wave data obtained at NOAA Buoy 44013 in Massachusetts Bay (see Fig. 1 for location). The largest near-bottom wave stress is associated with winds from the north and northeast (blowing toward the south and southwest). 

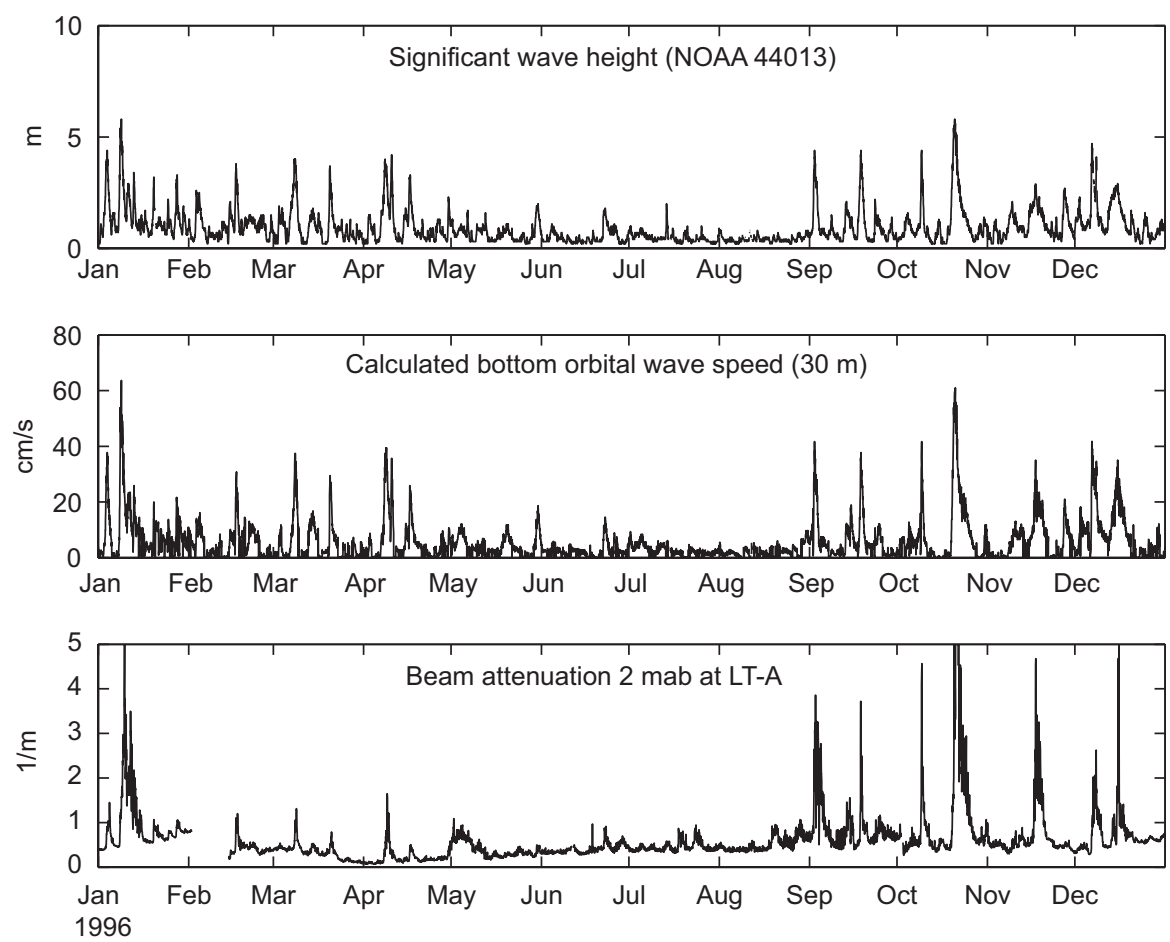

Fig. 4. Time series of significant wave height (measured at NOAA Buoy 44013, see Fig. 1 for location), bottom orbital wave speed at $30 \mathrm{~m}$ water depth (calculated from the surface wave observations), and beam attenuation (a measure of suspended sediment concentration) measured approximately $2 \mathrm{~m}$ above bottom at LT-A in western Massachusetts Bay for 1996. Increased bottom sediment concentrations occur in the near-bottom water whenever waveinduced currents are large. The 10th largest storm between 1990 and 2006, based on the integrated bottom wave stress, occurred on October 16, 1996 (see Table 2).

Table 2

Ten largest storms in Massachusetts Bay between 1990 and 2006, ranked by an integrated excess bottom stress (IES) at $30 \mathrm{~m}$ water depth when the bottom stress was greater than $0.1 \mathrm{~Pa}$ (see Storm Index, Section 2.2 for explanation)

\begin{tabular}{|c|c|c|c|c|c|c|c|c|c|}
\hline Rank & Start time & $\begin{array}{l}\text { Storm } \\
\text { duration (h) }\end{array}$ & $\begin{array}{l}\text { Vector- } \\
\text { averaged } \\
\text { wind stress } \\
(\mathrm{Pa})\end{array}$ & $\begin{array}{l}\text { Vector- } \\
\text { averaged wind } \\
\text { stress } \\
\text { direction } \\
\text { (degrees from) }\end{array}$ & $\begin{array}{l}\text { Average } \\
\text { significant } \\
\text { wave height } \\
\text { (m) }\end{array}$ & $\begin{array}{l}\text { Average } \\
\text { dominant } \\
\text { wave period } \\
\text { (s) }\end{array}$ & $\begin{array}{l}\text { Average } \\
u_{\text {wave }}^{*}(30 \mathrm{~m}) \\
\left(\mathrm{cm} \mathrm{s}^{-1)}\right.\end{array}$ & $\begin{array}{l}\text { Integrated } \\
\text { excess stress } \\
(30 \mathrm{~m}) \\
(\mathrm{Pah})\end{array}$ & $\begin{array}{l}\text { Duration } \\
u_{\text {wave }}^{*}>0.01 \mathrm{~m} \mathrm{~s}^{-1} \\
(80 \mathrm{~m})(\mathrm{h})\end{array}$ \\
\hline 1 & $11-$ Dec-92 $2^{\mathrm{a}}$ & 146 & 0.33 & 54 & 4.0 & 12.6 & 3.2 & 160 & 83 \\
\hline 2 & 28-Oct-91 & 128 & 0.33 & 24 & 3.7 & 11.4 & 2.8 & 116 & 43 \\
\hline 5 & 28-Jan-98 & 254 & 0.14 & 14 & 2.5 & 10.9 & 1.8 & 72 & 15 \\
\hline 6 & 23-Jan-05 & 52 & 0.44 & 359 & 4.7 & 11.3 & 3.3 & 65 & 25 \\
\hline 7 & 11-Dec-93 & 186 & 0.21 & 7 & 3.0 & 10.6 & 1.9 & 63 & 12 \\
\hline 8 & 31-Mar-97 & 76 & 0.30 & 4 & 3.8 & 10.1 & 2.6 & 56 & 23 \\
\hline 9 & 23-Oct-05 & 101 & 0.21 & 5 & 3.3 & 10.5 & 2.2 & 53 & 18 \\
\hline 10 & $19-$-Oct-96 & 141 & 0.11 & 71 & 2.8 & 10.9 & 2.0 & 52 & 8 \\
\hline
\end{tabular}

Wind stress and wind stress direction from which the wind blows (direction in degrees measured clockwise from north) are the components of vectoraveraged stress for the duration of the storm defined by wave bottom stress. No wind data are available for storm 4.

${ }^{\mathrm{a}}$ Modeled storms.

stress during the storms ranged between 359 and 71 degrees (the northeast quadrant) for all of the largest storms (there was no wind data for the March 2001 storm), consistent with the largest waves being associated with storms with winds from the northeast. The strongest storm, based on IES $_{30}$, occurred in December 1992 (the Blizzard of 1992) and the second strongest occurred in October 1991 (the Halloween Storm or the Perfect Storm). At $80 \mathrm{~m}$ water depth, characteristic of the deepest parts of Stellwagen Basin, the wave stress is attenuated compared to $30 \mathrm{~m}$; there were only 41 storms and $u_{w}^{*}$ exceeded $u_{c r i t i c a l}^{* 2}$ about $3 \%$ of the storm time at $30 \mathrm{~m}$. 


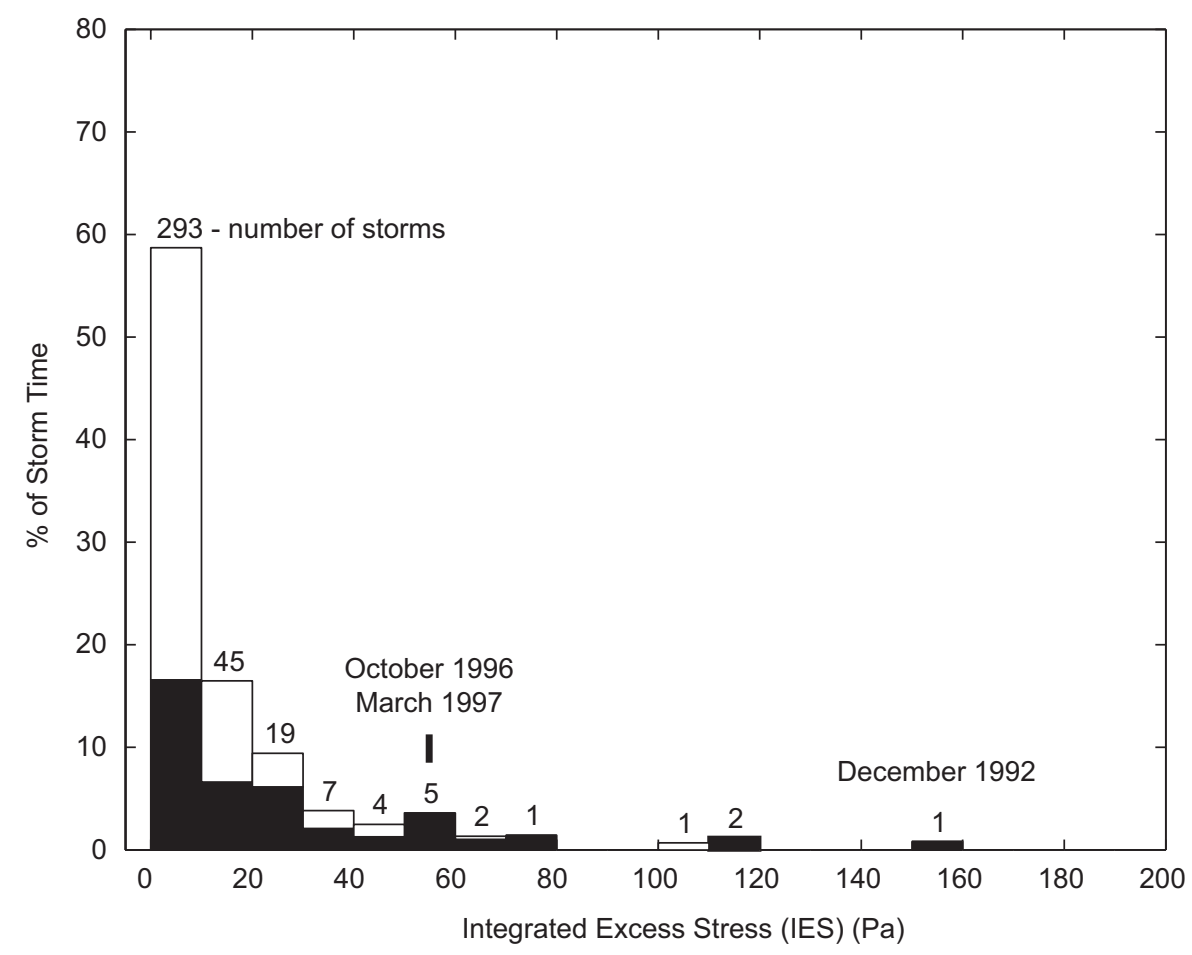

Fig. 5. Histogram of the percent of time of storms as a function of integrated excess stress (IES) at $30 \mathrm{~m}$ calculated from wave data from NOAA Buoy 44013 for the period 1990-2006. Storms with vector-averaged wind stress from 0 to 90 degrees are shown in black. The number at the top of each bar is the number of storms in that IES bin. The December 1992, October 1996 and March 1997 storms are modeled in this paper.

\subsection{Evaluating model performance}

The currents in Massachusetts Bay are driven by the tides, wind, river runoff (not included in the model simulations) and the Gulf of Maine coastal current. Before utilizing the model to explore storm-driven sediment transport in Massachusetts Bay, SWAN results were compared to observed waves during selected storms, and ROMS results were compared to the observed tidal elevation and current and to observations of wind-driven currents. All simulations and comparisons were carried out under well-mixed conditions typical of November to March.

\subsubsection{Waves during storms}

Surface waves were modeled for the December 1992, March 1997, and October 1996 storms. Simulations were performed for 8 days in non-stationary mode with a time step of $200 \mathrm{~s}$. Each simulation required $20 \mathrm{~h}$ on a dual $3 \mathrm{GHz}$ Xeon processor PC. Wind speed and direction for each storm were idealized to capture the main qualitative features of the storm, rather than to simulate the details of the event. Fig. 6 shows the wind forcing and SWAN predictions for the December 1992 storm. (Results for the other 2 storms are similar.) Winds for the December 1992 were linearly ramped from 0 to $22 \mathrm{~m} \mathrm{~s}^{-1}$ from 50 degrees capturing the qualitative behavior of the observed wind field (Fig. 6a and b). In the model simulations the wind direction was held constant in space and time to be consistent with measured data at the buoy, although in reality wind direction rotated at the end of the storm and most likely maintained intensity in the Gulf of Maine after passing the buoy. The direction change occurred after the wind speed decreased in magnitude and therefore was unimportant as a forcing. However, the continued intensity in the Gulf of Maine most likely generated swell that was unaccounted in the model simulations. Fig. 6c compares results from SWAN at the location of the NDBC Buoy to the values measured at the buoy. The predicted wave heights match the observed peaks in significant wave height $\left(H_{s}\right)$ for the December 1992 storm at $6.7 \mathrm{~m}$, with equally consistent results of 5.3, and 5.2 m for the March 1997 and October 1996 storms, respectively (not shown). The significant wave height predicted by SWAN is lower than measured near the end of the storm period, most likely caused by swell generated in the Gulf of Maine after the passage of the storm that was not included in the model. The predicted peak wave period of $13.6 \mathrm{~s}$ closely matches the observed value at the peak of the storm (Fig. 6d). The predicted peak period decreases with the wind strength, whereas the observed values remain higher from waves propagating from the Gulf of Maine. These mismatches in wave period occur at the end of the storm during periods of low wave height and do not affect sediment transport calculations. The last panel of Fig. 6 shows modelpredicted bottom-orbital velocities $\left(U_{b}\right)$ at the buoy of $0.47 \mathrm{~m} \mathrm{~s}^{-1}$, calculated from the entire wave spectrum. Estimates of the bottom orbital velocity are shown from 


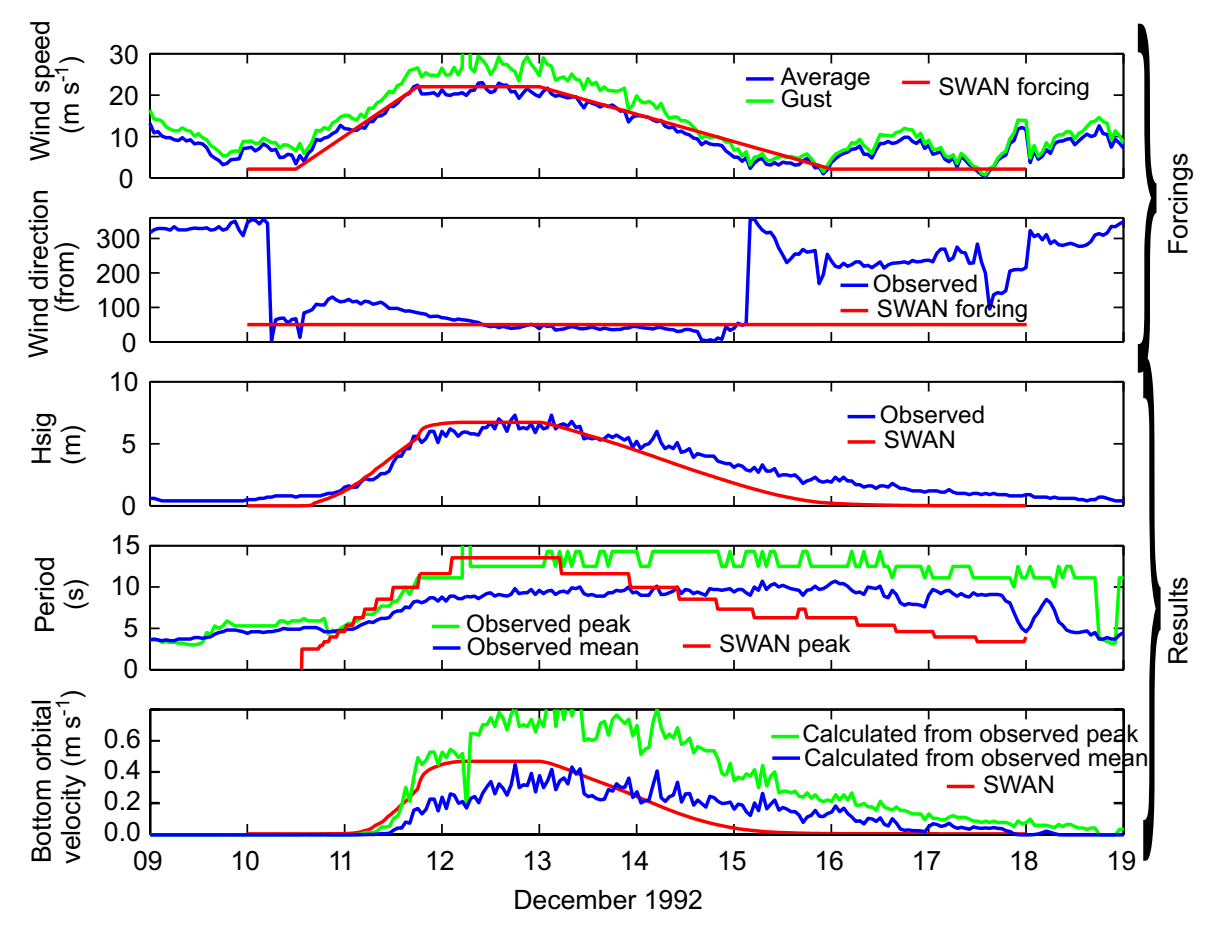

Fig. 6. Time series of wind and wave observations at NOAA Buoy 44013 in Massachusetts Bay, and modeled time series from SWAN (red) for December 1992 storm. Panels show (a) wind speed (average (blue), gust (green) and wind used in SWAN); (b) wind direction (observed (blue) and SWAN); (c) significant wave height (observed (blue) and predicted by SWAN); (d) wave period (observed peak period (green) and average period (blue), and SWAN peak period); and (e) bottom orbital velocity (at $55 \mathrm{~m}$ water depth) calculated from observed peak period (green) average period (blue), and SWAN (model integrates over wave spectrum).

linear wave theory and using the observed mean and peak wave periods. These estimates bracket the modeled values.

The SWAN predictions at the peak of the December 1992 storm show spatial variations in $U_{b}, H_{s}$, surface period $\left(T_{s}\right)$, and bottom period $\left(T_{b}\right)$ (Fig. 7). Magnitudes of $H_{s}$ increase along the wind direction in the Gulf of Maine (not shown), a result of the constant wind field applied over the model domain. However, the wave field is fully developed well to the east of Massachusetts Bay, and therefore the simulation has greater accuracy and relevance in the region of interest. Magnitudes of $U_{b}$ are inversely proportional to depth with maximum values along the coastline and on top of Stellwagen Bank. The peak surfacewave periods are on the order of $12 \mathrm{~s}$ in Massachusetts Bay and decrease in Cape Cod Bay, which is sheltered from the winds from the northeast. Peak bottom-wave periods show topographic variations with increased magnitudes in the deeper parts of the basin.

\subsubsection{Tides}

To assess the tidal hydrodynamics from the ROMS model, the predicted tidal elevations and currents were compared to observations. For this comparison the model was initialized from rest and forced with the seven tidal components from ADCIRC (as described previously) for 100 days. Tidal analysis using T-tide (Pawlowicz et al., 2002) was carried out on the model time-series and compared to the observed amplitudes and phases at 12 sites along the coast and in the interior of Massachusetts Bay (Appendix A, Tables A1 and A2). For the $\mathrm{M}_{2}$, the amplitude of the model tidal elevation was larger than observed by $4-8 \%$ throughout the bay (about $0.1 \mathrm{~m}$ ); the model elevation phase was within a few degrees of observed (Fig. 8). The amplitude of the major axis of the modeled $\mathrm{M}_{2}$ tidal current ellipse was also larger than observed (Fig. 9). At LT-A and GoMOOS-A, the locations with the longest data records and thus the best tidal estimates, the amplitude of the tidal ellipse was $4 \%$ and $8 \%$ larger than observed at 5 and $23 \mathrm{~m}$ below the surface, respectively. The phase of the modeled current ellipse was typically within about 5 degrees of observed, and the orientation and sense of rotation (especially where the tidal ellipse had a significant minor axis) were in good agreement with the model (Fig. 9). Note the increased phase lag of about 15 degrees in the $\mathrm{M}_{2}$ current south of Cape Ann, produced by the model and in agreement with observation. The differences between model elevation and currents compared to observations are a result of the forcing of the tides at the model boundary. We did not pursue a sensitivity analysis to adjust the boundary forcing to gain a closer agreement because the differences are not large enough to alter the conclusions derived in this modeling study.

\subsubsection{Wind-driven circulation}

The wind plays a key role in driving the low-frequency current fluctuations in Massachusetts Bay and the Gulf of 


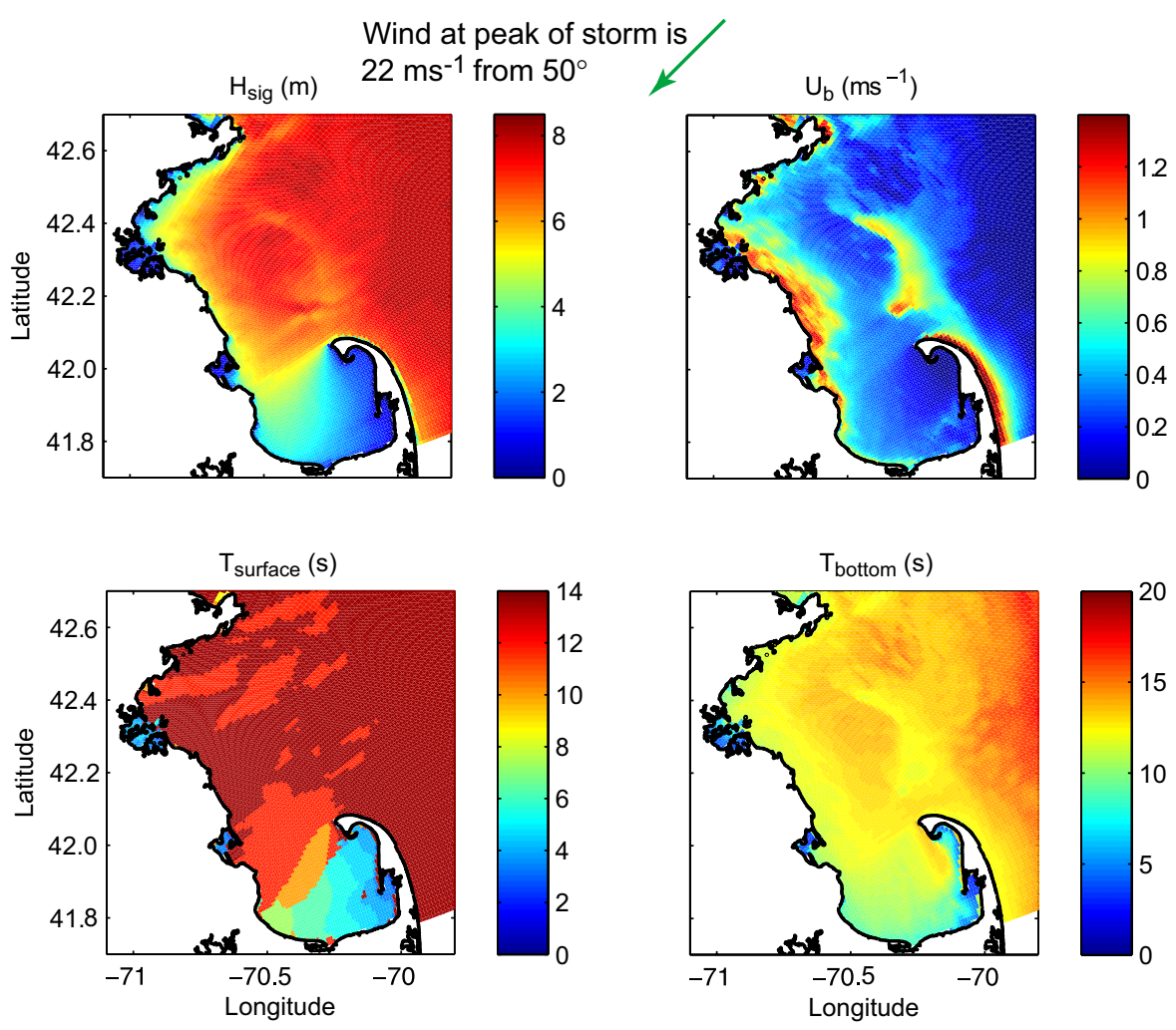

Fig. 7. Significant wave height $\left(H_{\text {sig }}\right)$, bottom orbital velocity $\left(U_{b}\right)$, peak surface period $\left(T_{\text {surface }}\right)$, and peak bottom period $\left(T_{\text {bottom }}\right)$ at peak of December 1992 storm (winds at $22 \mathrm{~m} \mathrm{~s}^{-1}$ from 50 degrees) calculated using SWAN.

Maine. The ROMS model domain extends about $150 \mathrm{~km}$ into the western Gulf of Maine to allow the wind-driven currents that affect Massachusetts Bay to develop. Simulations were carried out to determine the wind-driven flow pattern in Massachusetts Bay produced by winds from the N, NE, E, SE, and S (Fig. 10); the winds with a component from the east would also produce significant waves in Massachusetts Bay. For these simulations the model was initiated from rest and the wind was ramped to $10 \mathrm{~m} \mathrm{~s}^{-1}(0.14 \mathrm{~Pa})$ over a period of $12 \mathrm{~h}$ and sustained for 2 days, during which the residual flows reached steady state.

The semi-enclosed geometry of Massachusetts Bay produces a combination of wind-driven flow patterns expected for enclosed basins and a straight open coast. In all simulations, there is a component of surface flow in the direction of the wind in the shallow water along the coast in Massachusetts Bay and along the outer Cape. In steady state, sea level in Massachusetts Bay responds to an overall set-up or set-down from the Gulf of Maine. In addition, sea level adjusts within the Bay to produce no net flow across any cross section, driving flow opposite to the direction of the wind in deeper parts of Massachusetts or Cape Cod Bay. Net current speeds are $5-10 \mathrm{~cm} \mathrm{~s}^{-1}$ for a wind of $10 \mathrm{~m} \mathrm{~s}^{-1}$, causing net displacements of $10-20 \mathrm{~km}$ over a typical 2-day storm. Flows are weakest in Stellwagen Basin.

Winds from the north (Fig. 10) drive surface and bottom currents to the south in the shallow waters of western
Massachusetts Bay, on Stellwagen Bank, in Eastern Cape Cod Bay, and along the outer Cape. The free-surface response is a setup of the water level in Cape Cod Bay of approximately $0.07 \mathrm{~m}$. Bottom flow opposite to the direction of the wind occurs to the north in central Cape Cod Bay, and along the eastern edge of Stellwagen Basin. This flow connects to the southerly flowing coastal current from the Gulf of Maine along the seaward side of Stellwagen Bank.

Winds from the northeast (45 degrees, Fig. 10) are nearly perpendicular to the long axis of Massachusetts Bay and the wind-driven currents are weaker than for winds from the north. Near-surface currents are generally in the direction of the wind with strengths up to $0.2 \mathrm{~ms}^{-1}$ along the northern and southern ends of the bay. Near-bottom flow is to the southeast along the western shore of Massachusetts Bay at about $0.10 \mathrm{~ms}^{-1}$. There is a clockwise flow in eastern Cape Cod Bay that results from flow in the direction of the wind along the coast, and flow opposite to the direction of the wind in central Cape Cod Bay. There is a set-down of sea level in the southeast corner of Cape Cod Bay of a few $\mathrm{cm}$ and a setup of about $5 \mathrm{~cm}$ along the western shore of Massachusetts Bay.

Winds from the southeast (135 degrees, Fig. 10) are nearly parallel to the long axis of Massachusetts Bay and drive flow nearly the reverse of wind from the north. Flow is to the north in the shallow water along the western shore of Massachusetts Bay, on Stellwagen Bank and along the 


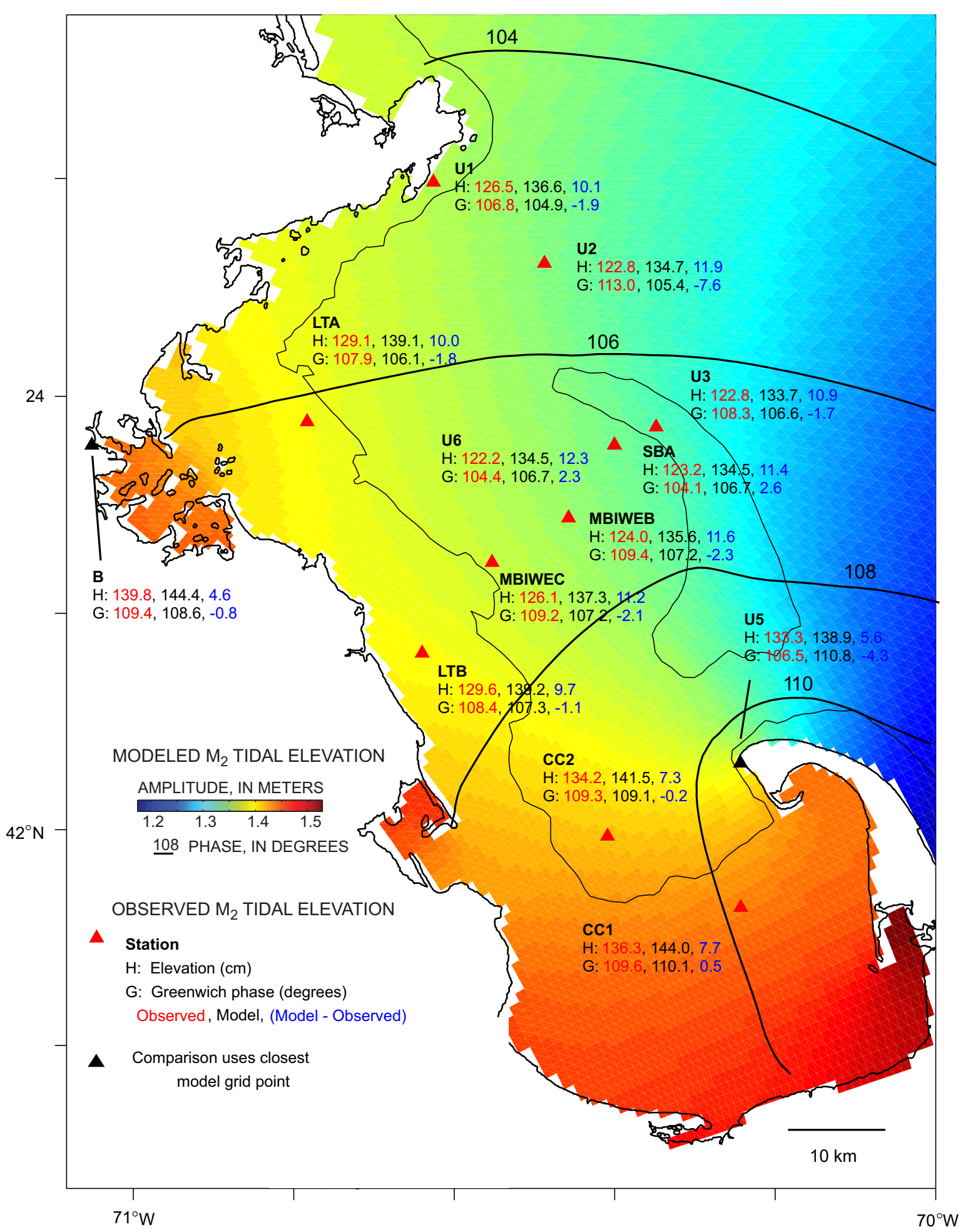

Fig. 8. Comparison of observed and predicted $\mathrm{M}_{2}$ tidal elevation (see Table 3). At each location, the observed and model elevation $(H)$ and phase $(G)$ and difference are shown. Background color is model elevation.

outer Cape. A relative set-down of approximately $0.05 \mathrm{~m}$ in Cape Cod Bay drives near-bottom flow to the eastern portion of Cape Cod Bay that upwells and connects to the northerly transport along the eastern shore. Bottom flow in Stellwagen Basin is to the southeast, opposite to the wind.
The steady wind-driven currents predicted by the model were compared to the long-term current observations made at LT-A between 1989 and 2002 and at LT-B between 1997 and 2002 (Butman et al., 2004a). The long-term observations at LT-A at 5 and $20 \mathrm{~m}$ were made by an ADCP and 


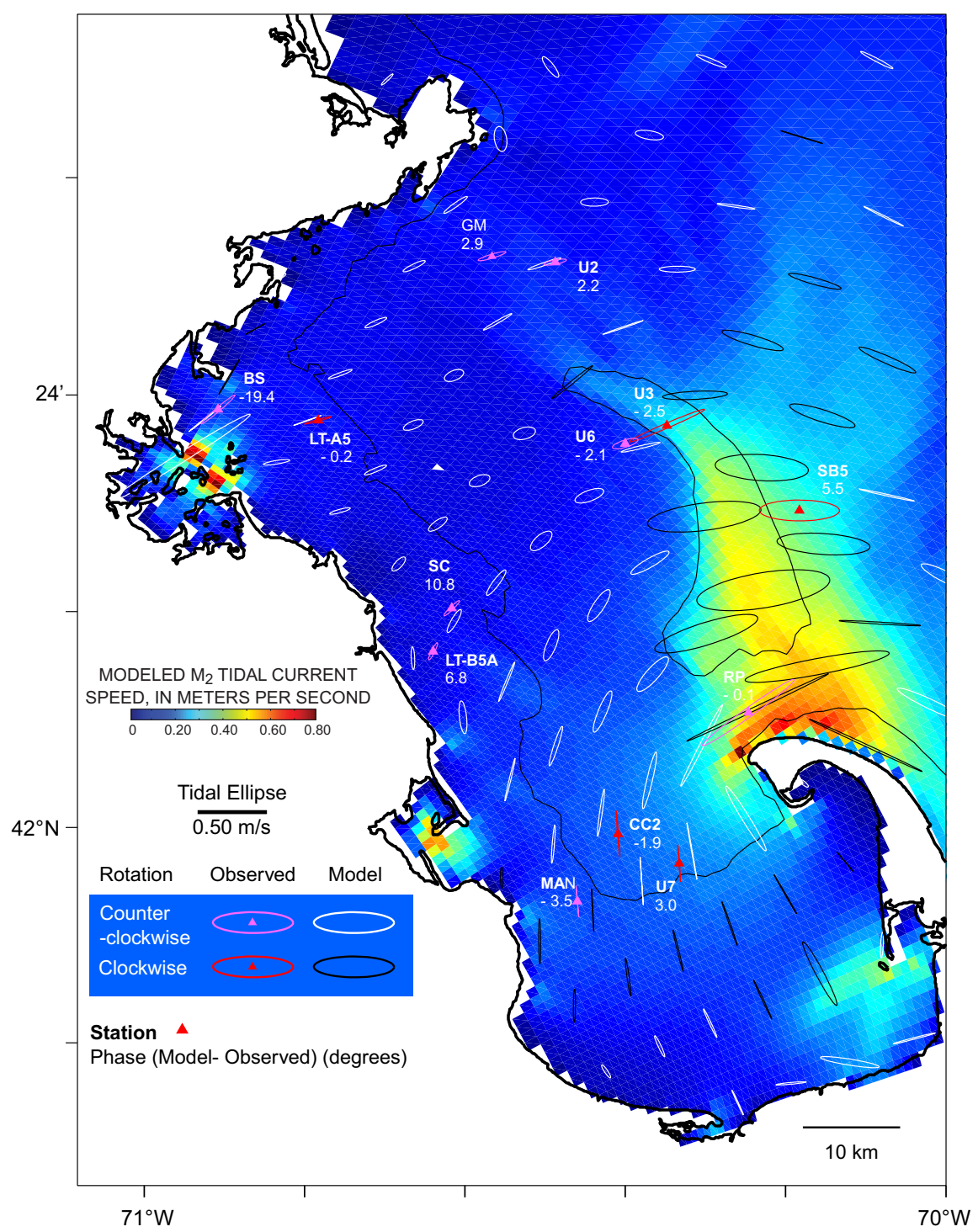

Fig. 9. Comparison of observed and predicted $\mathrm{M}_{2}$ tidal current ellipses. The number below the station identifier is the difference in phase between model and observation (positive phase difference means model leads data).

VMCM respectively. Observations at LT-B were made by an ADCP. A measure of the current associated with storm winds in 45 degree sectors was determined by vectoraveraging the observed low-passed currents (filter with a cut-off frequency near $30 \mathrm{~h}$ ) for times when the wind direction was in the quadrant and the wind stress magnitude exceeded $1.5 \mathrm{~Pa}$. Only data during winter (October through March) were used. The number of current observations in each direction bin ranged from 34 days at $10 \mathrm{mab}$ at LT-A for winds from the north, to less than 2 days at $5 \mathrm{~m}$ at LT-B for winds from the east; the most current observations during storms occurred for winds from the north or northeast. The variance in each wind-direction bin was typically $0.03-0.05 \mathrm{~m} \mathrm{~s}^{-1}$. The amplitude and direction of the binned observed stormdriven currents are in qualitative agreement with model predictions (Fig. 11) and provide confidence in the model's wind-driven currents. The observations show the reversal in the along-coast flow along the western shore of Massachusetts Bay from southeastward to northwestward as winds change from northeast to east.

\subsection{Sediment transport caused by northeasters}

Two numerical studies were carried out to explore the effects of northeast storms on the transport and fate of sediments. The first study consisted of a simulation to explore how a mixed bed of sediments of varying sizes would evolve under a series of the largest storms (typified by the December 1992 storm). In this experiment, we are conceptually thinking of how mixtures of sediments, such those left behind after the last glacial retreat, are redistributed by modern processes. However, this simulation is not intended to be realistic of the last 10,000 years because the retreating glaciers left behind a much wider distribution of sediment sizes (including gravel and 

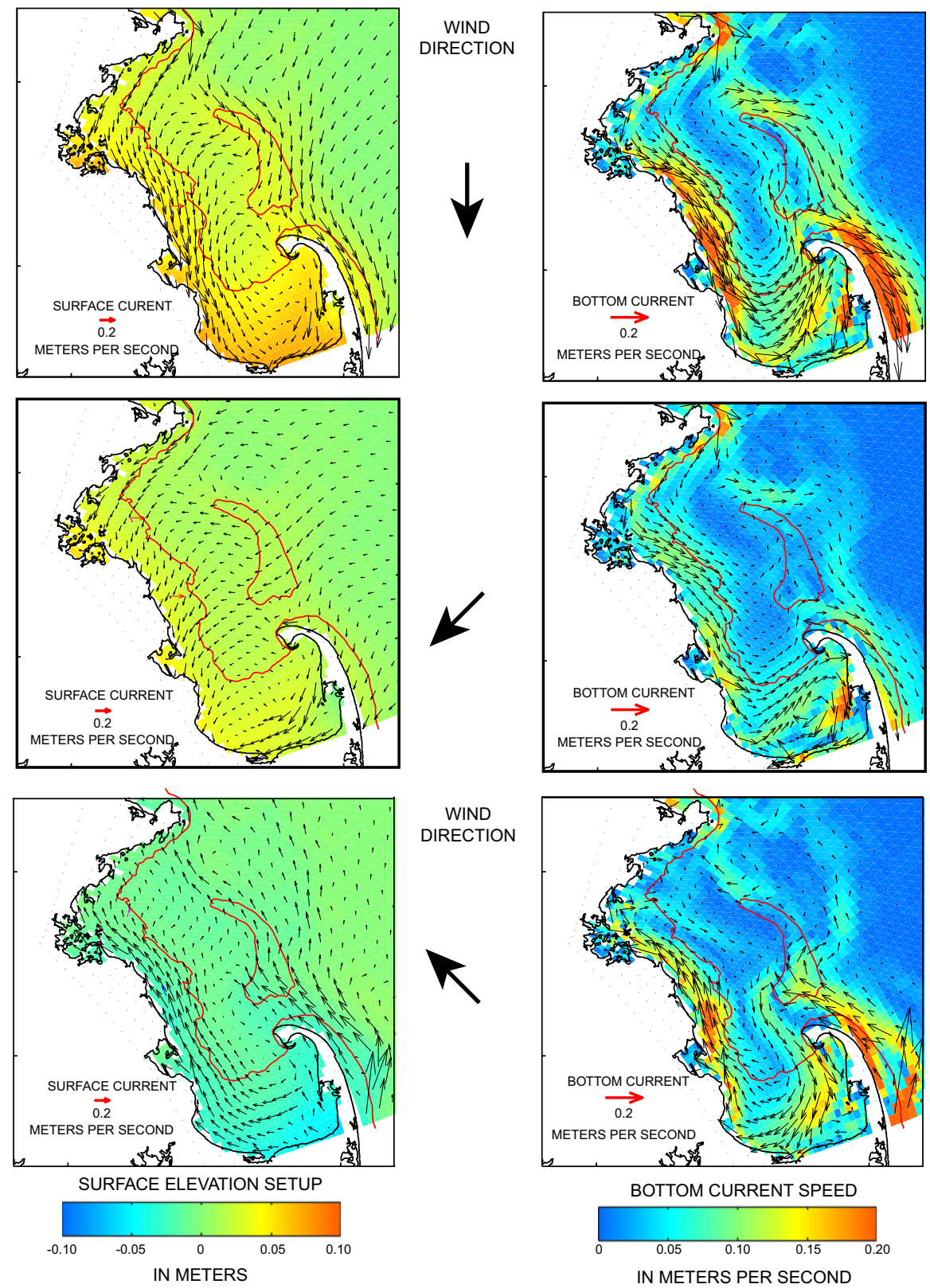

Fig. 10. Steady-state response of surface (left) and near-bottom currents (right) driven by a surface wind of $10 \mathrm{~m} \mathrm{~s}^{-1}$ (20 knots, surface stress of 0.14 Pa) from 0,45 , and 135 degrees (wind direction indicated by bold arrow). Arrows on the map show current magnitude and direction. Color indicates the surface elevation (left panels) and near-bottom current speed (right panels). The $40 \mathrm{~m}$ isobath is shown in red. The semi-enclosed geometry of Massachusetts Bay produces a wind-driven flow pattern where there is a component of surface flow in the direction of the wind in the shallow water along the coast in Massachusetts Bay and along the outer Cape, and flow opposite to the direction of the wind in deeper parts of Massachusetts or Cape Cod Bay (right panels). The flow along the western shore of Massachusetts Bay switches from southeastward to northwestward at winds from about 70 degrees.

boulders) and because other processes, most notably the transgression by rising sea level, played a major role in reworking and redistributing these sediments which are not modeled. The second study consisted of three simulations to explore the pathways and fate of sediments and associated contaminants in the bay. In this case, we are interested in the exploring the transport and fate of the tracer silver that was introduced into the Massachusetts Bay system from the discharge of sewage into Boston Harbor and that has accumulated in Cape Cod Bay and
Stellwagen Basin. Results from this simulation are also used to explore the residence time of material in Massachusetts Bay.

\subsubsection{Evolution of surficial sediment distribution}

In this simulation the sediment bed was initialized with 10 vertical levels: the top 6 layers at $0.01 \mathrm{~m}$ thick and the bottom 4 at $0.10 \mathrm{~m}$ thick, a porosity of 0.50 , and equal distributions of 7 sediment grain size fractions (Table 3). The sediments ranged from $7 \mathrm{phi}$ (fine silt, $0.0078 \mathrm{~mm}$ ) to 1 


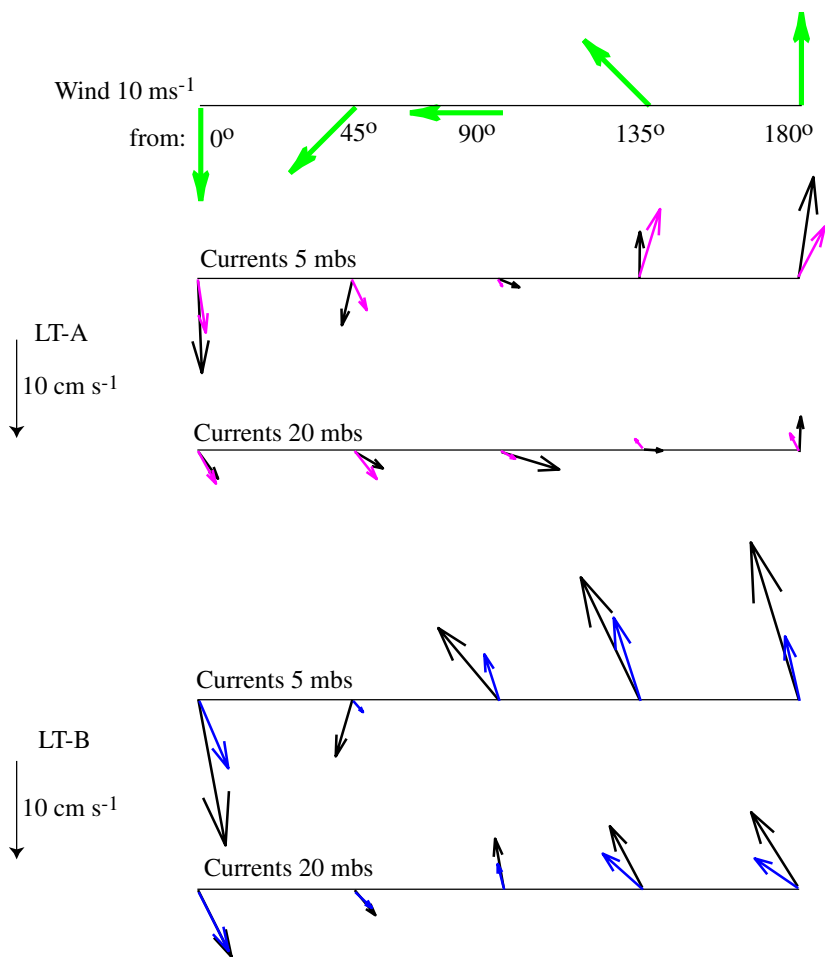

Fig. 11. Comparison of observed and predicted mean flow at 5 and $20 \mathrm{~m}$ for winds from $0,45,90,135$, and 180 degrees (wind direction indicated by green bold arrow). Arrows show current magnitude and direction from model (black) and from long-term moorings LT-A (magenta) and LT-B (blue).

Table 3

Characteristics of the 5 sediment classes used in the mixed-bed simulation

\begin{tabular}{llllll}
\hline $\begin{array}{l}\text { Sediment } \\
\text { class (phi) }\end{array}$ & $\begin{array}{l}\text { Diameter } \\
(\mathrm{mm})\end{array}$ & $\begin{array}{l}\text { Density } \\
\left(\mathrm{kg} \mathrm{m}^{-3}\right)\end{array}$ & $\begin{array}{l}\text { Settling } \\
\text { velocity } \\
\left(\mathrm{mm} \mathrm{s}^{-1}\right)\end{array}$ & $\begin{array}{l}E_{0} \\
\left(\mathrm{~kg} \mathrm{~m}^{-2} \mathrm{~s}^{-1}\right)\end{array}$ & $\begin{array}{l}\tau_{c e} \\
(\mathrm{~Pa})\end{array}$ \\
\hline 1 & 0.50 & 2650 & 57.0 & $5.0 \mathrm{e}-6$ & 0.27 \\
2 & 0.25 & 2650 & 27.0 & $5.0 \mathrm{e}-6$ & 0.19 \\
3 & 0.125 & 2650 & 8.7 & $5.0 \mathrm{e}-6$ & 0.14 \\
4 & 0.0625 & 2650 & 2.4 & $5.0 \mathrm{e}-6$ & 0.09 \\
5 & 0.03125 & 2650 & 0.62 & $5.0 \mathrm{e}-6$ & 0.061 \\
6 & 0.0156 & 2650 & 0.15 & $5.0 \mathrm{e}-6$ & 0.038 \\
7 & 0.0078125 & 2650 & 0.0387 & $5.0 \mathrm{e}-6$ & 0.022 \\
\hline
\end{tabular}

$E_{0}$ is the bed erodibility constant and $\tau_{c e}$ is the critical shear stress for erosion.

phi (coarse sand, $0.50 \mathrm{~mm}$ ) material with critical erosion velocities ranging from 0.022 to $0.27 \mathrm{~Pa}$, respectively. The simulation was initiated with the domain at rest and allowed to "spin up" for 10 days with tidal forcing $\left(\mathrm{M}_{2}, \mathrm{~S}_{2}\right.$, $\mathrm{N}_{2}, \mathrm{~K}_{2}, \mathrm{O}_{1}, \mathrm{~K}_{1}$, and $\mathrm{Q}_{1}$ constituents) along the open boundary. After the spin-up time period, the surface wind stress and wave field for the December 1992 storm (same simulation as described for Fig. 6) were imposed which constituted an 8-day storm period. This storm period and an additional 1 day period to allow sediment to settle out of the water column were repeated 10 times to simulate a cycle of large storm events. The model time step was $30 \mathrm{~s}$ and results were saved hourly. Simulations required $20 \mathrm{~h}$ of computational time on a 4 processor UNIX Dec-Alpha DS20E, $667 \mathrm{MHz}$ system.

Results from the repeating storm simulation identify locations of increased bottom stress, sediment resuspension, and bathymetric change (Fig. 12). The instantaneous bottom stress (maximum combined wave-current stress) at the peak of storm activity is greatest in the shallow water along the coastline and on the crest of Stellwagen Bank and Jeffreys Ledge, mirroring locations of increased bottom orbital velocities from the wave model (Fig. 7). Stresses are lower in Stellwagen Basin where the near-bottom wave currents are attenuated in the deep water, and in Cape Cod Bay because the Cape shelters the Bay from waves from the northeast. Along the western shore of Massachusetts Bay, combined wave and current stress is high between Boston and Plymouth, and then decreases between Plymouth and Barnstable. The instantaneous suspended-sediment concentrations during the storm (not shown) are greatest in the regions of highest stress and are lowest in Cape Cod Bay and in Stellwagen Basin. At the end of the simulation, net erosion has occurred along the crest of Stellwagen Bank and Jeffreys Ledge, along the western shore of Massachusetts Bay north of Plymouth, in Eastern Cape Cod Bay, and along the outer arm of Cape Cod, reaching maximum values of $0.02 \mathrm{~m}$ (Fig. 12b). Deposition occurs south of Cape Ann, in eastern Stellwagen Basin immediately west of Stellwagen Bank, and in Cape Cod Bay in a band extending from the Cape Cod Canal to Provincetown. A region of deposition occurs south of Plymouth; this depositional area results from the material eroded and transported from the area north of Plymouth, and may eventually erode as this source is reduced.

The surficial grain size distribution after 10 storms (Fig. 12c) has approached a steady state, with continued small changes that do not significantly alter the pattern described here. The sediment texture is coarser in regions of high stress and finer in areas of low stress. The surficial sediment texture qualitatively resembles the observed distribution (Fig. 12d; Poppe et al., 2003). The crest of Stellwagen and Jeffreys Ledge, the outer Cape, and the western shore of Massachusetts Bay north of Plymouth have been winnowed to the 2-3 phi sediment class and the sediment deposition south of Cape Ann, and in Cape Cod Bay and Stellwagen Basin has resulted in a surficial texture of 5-6 phi material. The material east of Stellwagen Bank is slightly finer in the model, possibly due to the lack of the Gulf of Maine coastal current, which could transport the 4 and 5 phi material further to the south.

A transect across Massachusetts Bay shows the size-class changes in areas of net sediment accumulation on the flanks of Stellwagen Bank and in Stellwagen Basin, and in areas of erosion in shallow water along the western shore and on the top of Stellwagen Bank (Fig. 13). On the western side of Stellwagen Bank net sediment accumulation begins at about $40 \mathrm{~m}$ water depth caused by deposition of 4 phi material. On the eastern side of Stellwagen Bank net 
A

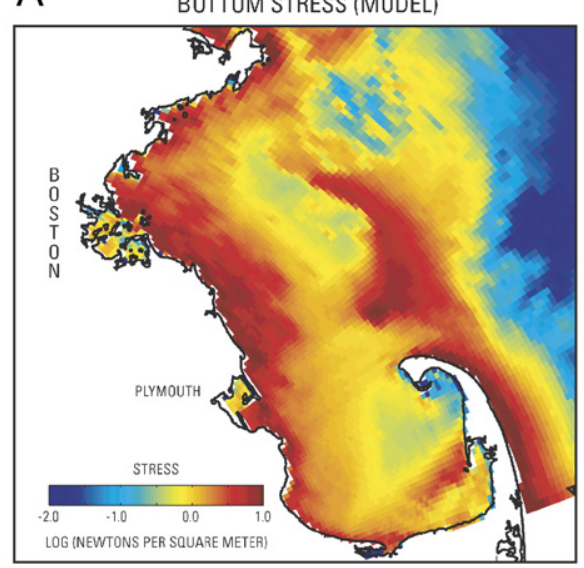

C SEDIMENT GRAIN SIZE (MODEL)

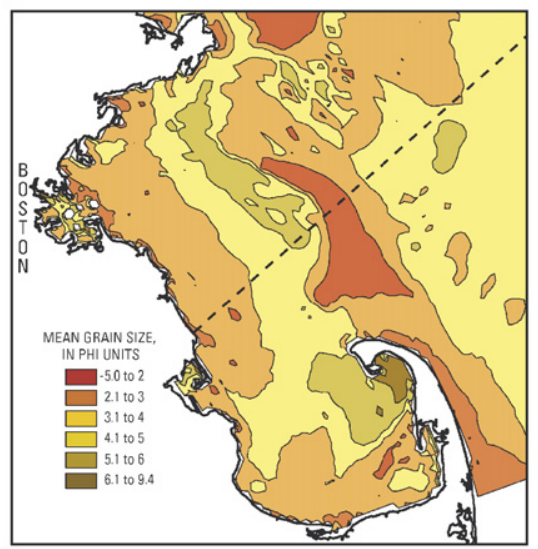

B BATHYMEtRY CHANGE (MODEL)

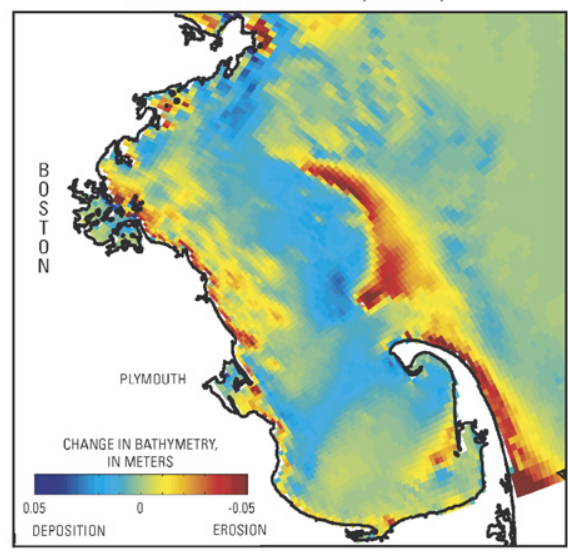

D

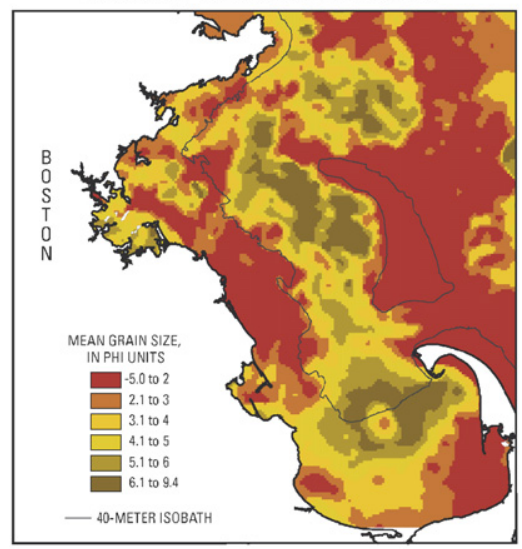

Fig. 12. Results from model simulation of the evolution of a mixed sediment bed in response to a sequence of 10 idealized northeast storms, modeled after the December 1992 storm with winds from 50 degrees. Panels show the instantaneous wave-current bottom stress at the peak of storm (A), the change in bathymetry (B) and the final mean surficial grain size (C) following the 10-storm sequence. The observed surficial grain size distribution (D) qualitatively matches the evolved sediment texture $(\mathrm{C})$. The line in panel $\mathrm{C}$ is the location of the sediment transect shown in Fig. 13.

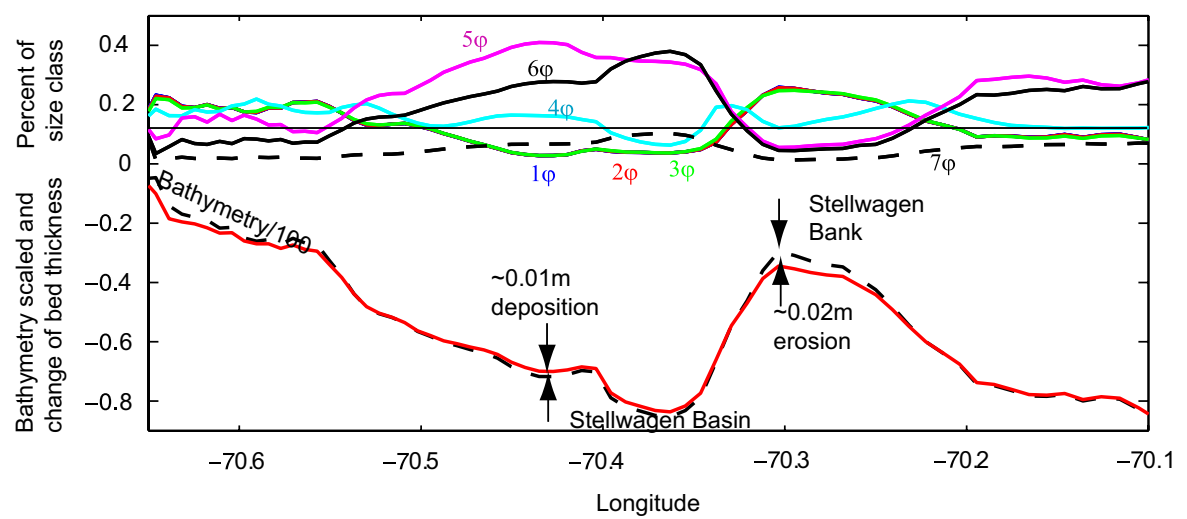

Fig. 13. Percentage of surficial sediment of each sediment size class in the top bed layer and the change in bed thickness along a transect from the western shore of Massachusetts Bay to the Gulf of Maine following 10 idealized storms similar to the December 92 storm (see Fig. 12 for transect location). The model was initialized with an even distribution of $1,2,3,4,5,6$, and 7 phi-sized material ( $14.3 \%$ each class). Note that the final concentrations of 1,2 and 3 phi-sized sediments are nearly identical.

sediment accumulation begins at about $65 \mathrm{~m}$ water depth caused by deposition of 5 and 6 phi-sized material. In the deepest part of Stellwagen Basin net sediment accumulation is caused by deposition of 5 and 6 phi-sized materials.
On the western shore of Massachusetts Bay sediment erosion begins at about $50 \mathrm{~m}$ water depth, leaving behind 1 , 2, 3 and 4 phi-sized material. On Stellwagen Bank, sediment erosion leaves a lag of 1,2, 3 and 4 phi-sized 


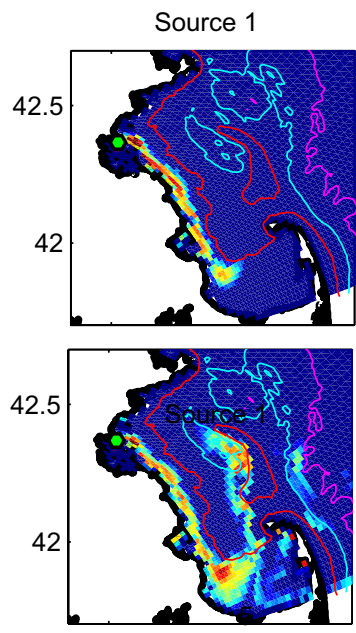

Source 4
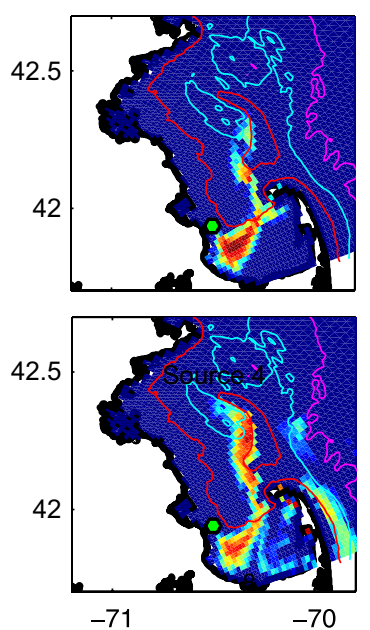

$-71$

Winds from $12^{\circ}$

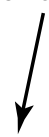

Source 2
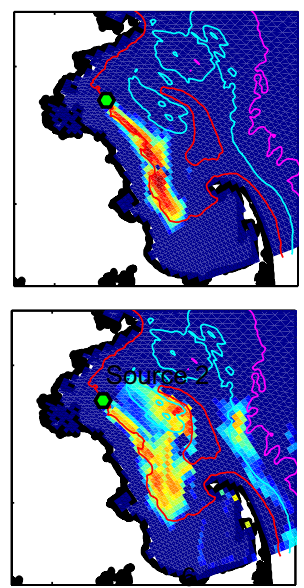

Source 6
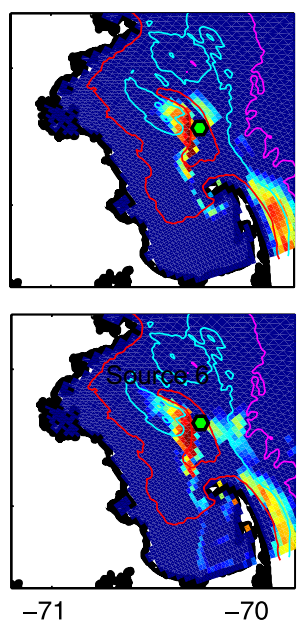

Source 3
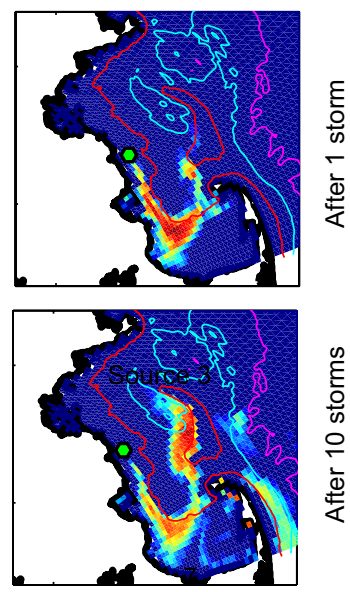

Source 8
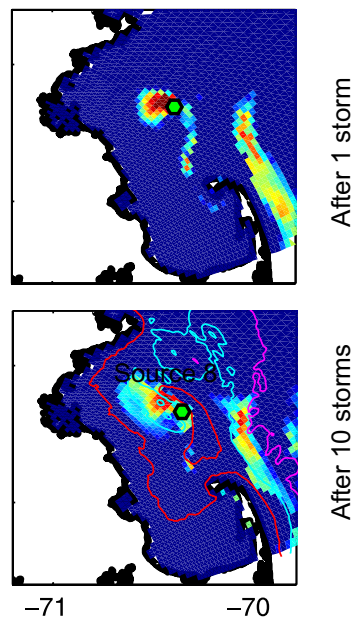

$\mathbf{0}$

source

ACCUMULATED SEDIMENT AS A FR ACTION OF TOTAL AMOUNT OF DEPOSITED SEDIMENT, IN PERCENT

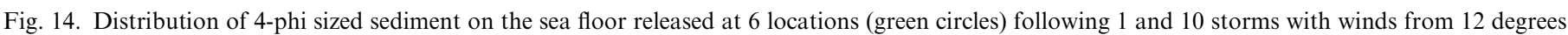

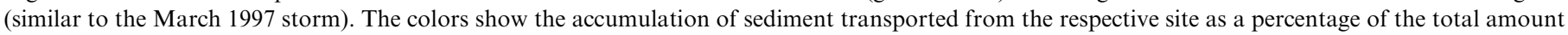

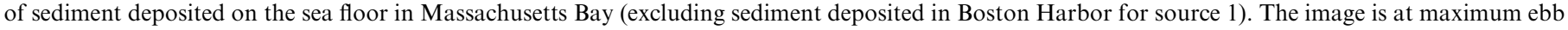

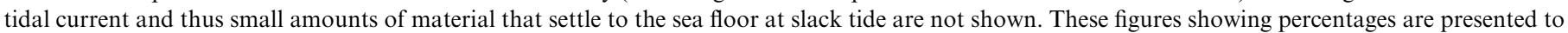
identify transport pathways; the colors do not show the absolute amount of material on the sea floor.

material. At all locations, some of the 7 phi material was eroded, with the minimal erosion of 7 phi in Stellwagen Basin.

\subsubsection{Transport pathways}

To identify the pathways of sediment transport caused by storms, simulations were carried out with sediment placed on the seafloor at eight locations in Massachusetts Bay: (1) entrance to Boston Harbor ( $7 \mathrm{~m}$ water depth), (2) LT-A near the new ocean outfall ( $37 \mathrm{~m}$ water depth), (3) offshore of Scituate (23 m water depth), (4) northwest corner of Cape Cod Bay (28 m water depth), (5) southern end of Stellwagen Bank (34 m water depth), (6) middle of Stellwagen Bank (33 m water depth) (7) northern end of
Stellwagen Bank (29 m water depth), and (8) Stellwagen Basin (89 m water depth) (Figs. 14-16. Locations 5 and 7 not shown). At each location, one grid cell of the sea floor was initialized with a $1 \mathrm{~m}$-thick layer (essentially infinite for these simulations) of 4 phi-sized sediment (very fine sand, diameter $0.0625 \mathrm{~mm}$ ). This size material was chosen because it moves as suspended sediment (i.e. the critical stress for movement is sufficient to keep the material in suspension) but it has a settling velocity high enough that the material is not too dispersed and thus allows identification of the travel pathways. Three storms were selected to examine sediment transport pathways under winds that drive varying flow patterns in Massachusetts Bay; one with winds from 12 degrees (similar to the March 


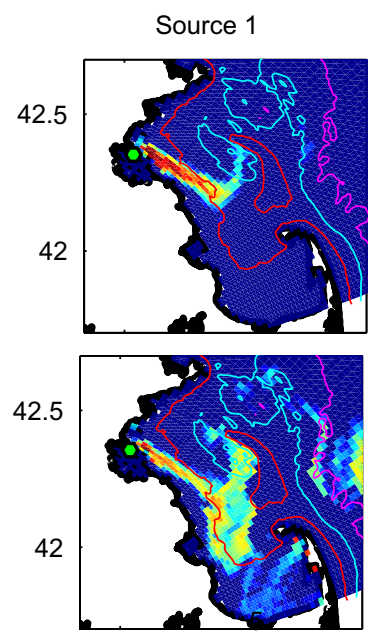

Source 4
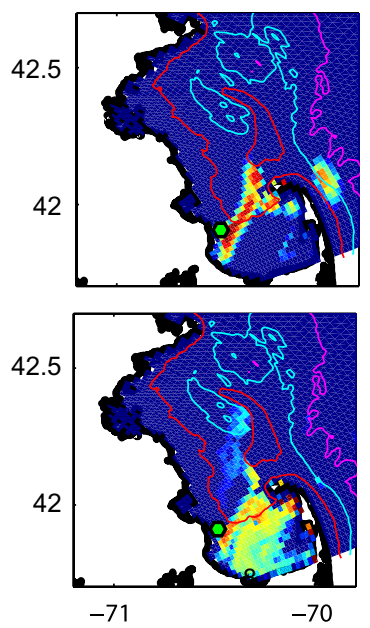

Winds from $50^{\circ}$

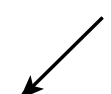

Source 2
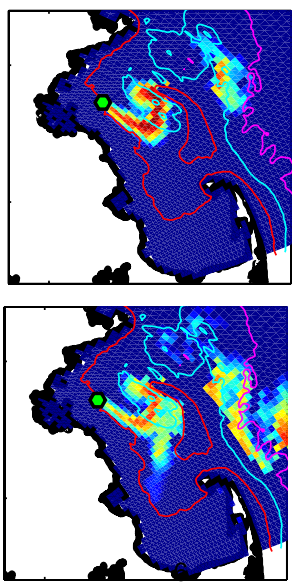

Source 6
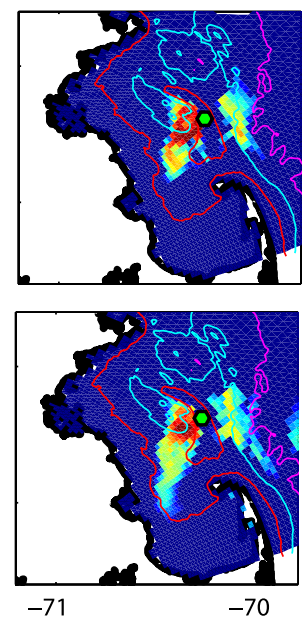

0.001

0.01

0.1

ACCUMULATED SEDIMENT AS A FRACTION OF TOTAL
AMOUNT OF DEPOSITED SEDIMENT, IN PERCENT

Fig. 15. Distribution of 4-phi sized sediment on the sea floor released at 6 locations (green circles) following 1 and 10 storms with winds from 50 degrees (similar to the December 1992 storm). The colors shows the accumulation of sediment transported from the respective site as a percentage of the total amount of sediment deposited on the sea floor in Massachusetts Bay (excluding sediment deposited in Boston Harbor for source 1). The image is at maximum ebb tidal current and thus small amounts of material that settle to the sea floor at slack tide are not shown. These figures showing percentages are presented to identify transport pathways; the colors do not show the absolute amount of material on the sea floor.

1997 storm), one with winds from 50 degrees (similar to the December 1992 storm), and one with winds from 70 degrees (similar to the October 1996 storm). These storms are the 8th, 1st, and 10th largest, respectively, based on wave observations between 1990 and 2006 and the integrated excess wave stress (Table 2). The model simulations are driven by waves (from SWAN), the combined tidal constituents and surface wind stress. The combined wave and current stress associated with these storms is sufficient to resuspend the sediment $\left(\tau_{c e}=0.09 \mathrm{~Pa}\right)$ throughout the Bay. The storm is repeated 10 times, each storm separated by about 2 days, allowing sediment to settle following resuspension. The storm separation is not an integral tidal cycle, so the resuspension and settlement occurs at different phases of the tide over the 10-storm simulation. The distribution of material on the sea floor for each simulation is shown after the first storm to illustrate the short-term trajectory of particles and after 10 storms to illustrate the cumulative distribution (Figs. 14-16). Because the sediment is introduced at only one grid cell and the sediment is distributed over a large area, the amount deposited on the sea floor is very small (a layer of order $10^{-5} \mathrm{~m}$ thick), and new deposits are typically resuspended entirely by subsequent storms (with a few exceptions, see below). Suspended sediment concentrations are $10^{-4} \mathrm{~kg} \mathrm{~m}^{-3}$. Pathways from sources 5 and 7 are not shown in the set of figures as these tracks closely follow those from source 6 . 


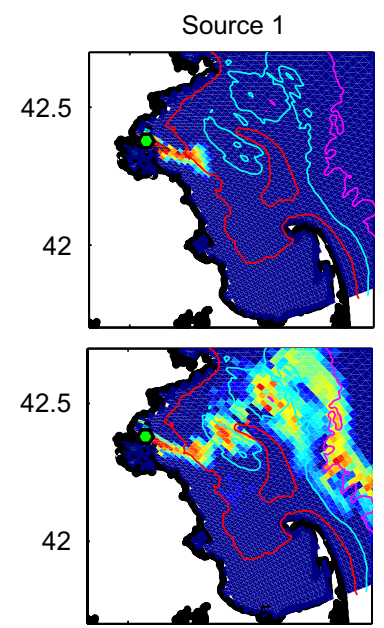

Source 4
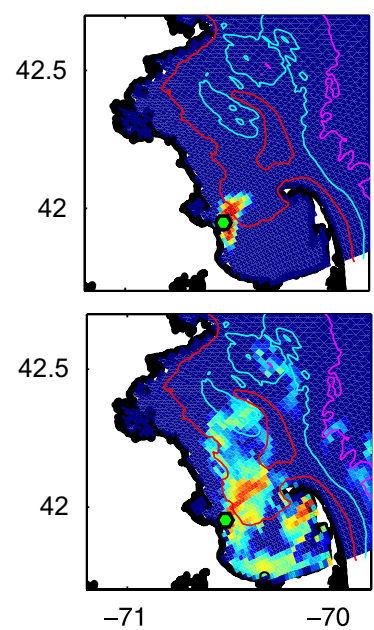

Winds from $70^{\circ}$

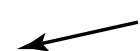

Source 2
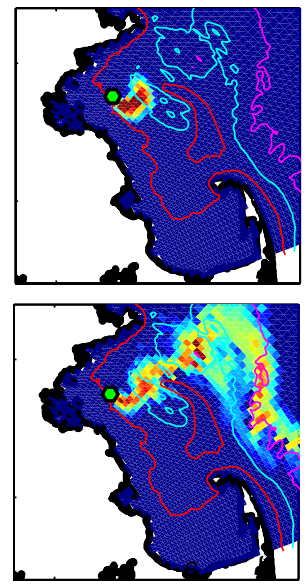

Source 6
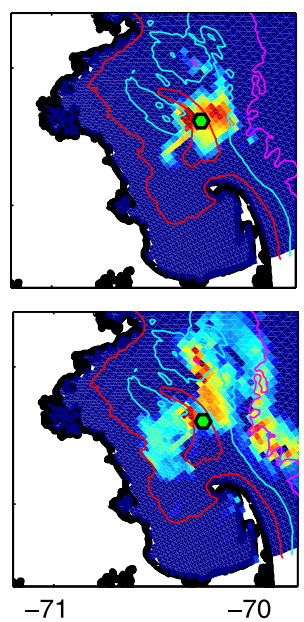

0.001

0.01

0.1

0.1

ACCUMULATED SEDIMENT AS A FR ACTION OF TOTAL

AMOUNT OF DEPOSITED SEDIMENT, IN PERCENT

Fig. 16. Distribution of 4-phi sized sediment on the sea floor released at 6 locations (green circles) following 1 and 10 storms with winds from 70 degrees (similar to the October 1996 storm). The colors shows the accumulation of sediment transported from the respective site as a percentage of the total amount of sediment deposited on the sea floor in Massachusetts Bay (excluding sediment deposited in Boston Harbor for source 1). The image is at maximum ebb tidal current and thus small amounts of material that settle to the sea floor at slack tide are not shown. These figures showing percentages are presented to identify transport pathways; the colors do not show the absolute amount of material on the sea floor.

4.3.2.1. Transport under winds from 12 degrees (March 1997 storm). Sediment from sources 1, 3 and 4 (Boston Harbor, Scituate, and Cape Cod Bay) is transported southeastward along the western shore of Massachusetts Bay, northeastward into Cape Cod Bay near the Cape Cod Canal, and then northerly into Stellwagen Basin (Fig. 14). Some of the material is transported to the east through Race Point Channel into the Gulf of Maine, where it deposits to the east of Cape Cod, and exits the system via the southerly coastal current on the seaward side of Stellwagen Bank. The remaining material from sources 1, 3 and 4 is advected northward into Stellwagen Basin, where it deposits and is then resuspended and advected across Stellwagen Bank, again into the southerly coastal current.
Sediment from source 2 is also transported southeastward and offshore into Stellwagen Basin but does not travel into Cape Cod Bay. During non-storm conditions, some of the sediment from sources 5 and 6 (southern and middle Stellwagen Bank) is resuspended by the tidal current that flows across Stellwagen Bank. During storms some sediment from sources 5,6 , and 7 is transported by the tidal currents eastward into the coastal current and some westward into Stellwagen Basin. The material deposited in Stellwagen Basin is subsequently resuspended and transported eastward over Stellwagen Bank and into the coastal current. After 10 storms material from the top of Stellwagen Bank accumulates in eastern Stellwagen Basin and in a northwest-southeast-trending strip to the east of 
Stellwagen Bank and Cape Cod. Material transported from source 8 follows a similar pattern as sources $5-7$, but there is less material resuspended from this deep location.

East of Cape Cod, sediment deposition occurs in strips oriented in the along-isobath direction. The inner-most strip of accumulation that occurs between the 40 and $80 \mathrm{~m}$ isobath to the east of Cape Cod reflects material transported through Race Point channel. Other strips reflect interaction between the phase of the tide. The accumulation at the eastern edge of the model domain is in a topographic low.

\subsubsection{Transport under winds from 50 degrees (December} 1992 storm). Sediment from source 1 in Boston Harbor is transported southeastward offshore towards Stellwagen Basin (Fig. 15). Some of the sediment is transported northeastward over Stellwagen Bank and exits Massachusetts Bay into the coastal current. After the first storm, material deposited nearshore to the southeast of Boston is resuspended. The remaining sediment is transported southeastward along the eastern shoreline and either exists through Race Point or enters a clockwise rotating gyre in Cape Cod Bay. Sediment from sources 3 and 4 from the eastern shoreline is also transported southeastward along the shoreline and enters the clockwise circulation in Cape Cod Bay. A portion of the mass from source 4 bifurcates northward into Stellwagen Basin. Most likely some material from sources 1 and 3 also travel this path, but are below the detection level for this analysis. Sediment from source 2 released near the outfall is initially directed towards Stellwagen Basin and then turns northward to be transported around the northern end of Stellwagen Bank. This material is then transported in the coastal current out of the domain. Sediment from sites 5 and 6, atop Stellwagen Bank, follow trajectories similar to each other. Bottom stress caused by the tidal currents alone is high enough to resuspend some of the material. With the start of the first storm more material is resuspended. At site 5 about half of the suspended sediment is immediately advected seaward of Stellwagen Bank and lost to the coastal current. The other half of the sediment and almost all of the material from site 6 is advected landward to deposit on the seafloor in Stellwagen Basin. This material is subsequently resuspended and advected out of the system over Stellwagen Bank.

\subsubsection{Transport under winds from 70 degrees (October} 1996 storm). Sediment from source 1 is advected eastward from Boston Harbor past the outfall site and leaves Massachusetts Bay north of Stellwagen Bank (Fig. 16). Sediment resuspended from site 2 follows a very similar transport trajectory to material from source 1 . Sediment from source 3 offshore of Scituate is transported north along the eastern shore and joins the trajectory from 1 and 2. Material resuspended from site 4 is advected in the clockwise circulation around Cape Cod Bay, with some sediment transported north towards Stellwagen Basin.
Sediment from sites 5 and 6 is again resuspended by the tidal current alone, but is primarily advected by storm transport. A portion of the sediment is transported eastward out of Massachusetts Bay. The remaining material is transported into Stellwagen Basin and follows a trajectory northward around Stellwagen Bank. Material from sites 7 and 8 follows similar patterns with some sediment immediately transported eastward out of the system and the remaining sediment transported north.

\subsubsection{Sediment export and retention}

The repeated storm results were analyzed to determine relative amounts of eroded material that exited or remained in Massachusetts Bay. For these calculations, Massachusetts Bay is defined as the area to the west of a line extending from Cape Ann southward along the seaward side of Stellwagen Bank to Cape Cod. The simulations used 4-phi sediments. The initial sediment mass at each point source was much larger than the amount resuspended during each storm to ensure an adequate supply of material for the duration of the simulations. Results are presented for eight sources after ten storms modeled after the December 1992 storm (Fig. 17). Results from the other storms are qualitatively similar. The percentage of material removed from each of the eight sites after ten storms was divided into the relative percentage exported from Massachusetts Bay and the relative percentage that remained within the Bay (exclusive of that remaining at the site). Because of the large source of sediment, the percentages are arbitrary, but the differences between sites indicate relative differences in the amount of material eroded and their fate.

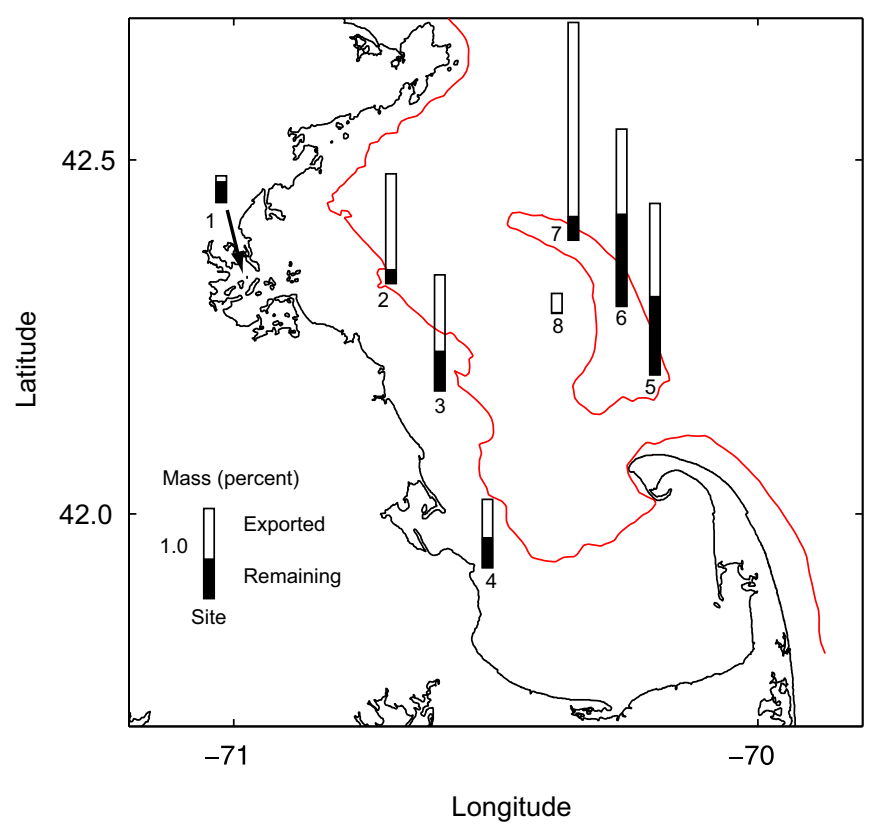

Fig. 17. Percent mass, from each of 8 sources, exported from and remaining in Massachusetts Bay after 10 repeated December 1992 storms. The absolute percentage is arbitrary. 
The smallest amount of material was eroded from source 8 in Stellwagen Basin where the waves are attenuated in the deep water and the wave bottom stress is small (Fig. 12a); almost all the material eroded from this site is transported outside of Mass Bay. A similarly small amount of material was eroded from source 1 in Boston Harbor. The model does not resolve Boston Harbor well and thus the details of the exchange between the Harbor and Bay are only generally correct, but the weaker waves in the sheltered harbor cause less resuspension and thus slower removal of sediment. Most of the material eroded in the harbor remains in the Bay, most likely in the harbor itself. Source 4 is somewhat sheltered from waves from the northeast (Fig. 12a) and the amount of material removed is less than at sites 2 and 3 that are exposed to larger waves. About $50 \%$ of the material eroded from site 4 is retained in Massachusetts Bay, probably most in Cape Cod Bay (Fig. 15). Most of the material eroded from source 2 leaves Mass Bay, exiting north of Stellwagen Bank (Fig. 15). Approximately equal amounts of sediment eroded from sources 5 and 6 are exported and remain in the Bay. The most material in this simulation was removed from source 7 , most likely a result of the near-bottom offshore transport at this site for winds from the northeast (Fig. 10).

\section{Discussion}

The numerical simulations of suspended-sediment transport show that the transport primarily follows the direction of the mean wind-driven circulation during storms. Winds from the north (Fig. 10a) drive a well-defined counterclockwise circulation in Massachusetts Bay and the suspended sediment transport for the March 1997 storm (winds from 12 degrees) follows that circulation (Fig. 14). For winds from 45 degrees, the strength of the wind-driven circulation decreases (Fig. 10b). The mean circulation of suspended sediment tends to be counterclockwise, but sediment from sites 1 and 2 is not captured by a strong southerly flow along the shoreline but rather is transported across the Bay and exits at the northern end of Stellwagen Bank, as shown for the December 1992 storm (Fig. 15). For winds from 90 degrees (not shown), the flow and sediment transport along the eastern shore is to the north. The October 1996 storm had winds from 70 degrees (not 90 degrees) but the resulting transport patterns are similar to the wind test case from 90 degrees. At a wind direction of about 60 degrees (the direction normal to the coast) the along-coast flow changes from southeastward to northwestward; winds from directions less than 60 degrees drive transport to the south and winds from directions greater than 60 degrees drive transport to the north along the eastern shoreline. With winds from 90 degrees the clockwise circulation in Cape Cod Bay and the offshore flow out of Boston Harbor are both strengthened. The suspended sediment transport from Boston Harbor is directed more offshore in response to these flow patterns.
The transport pathways of sediments from site 1 are consistent with Boston Harbor being the long-term source of silver found in the surficial sediments in Cape Cod Bay and Stellwagen Basin. Storms with winds from 0 degrees to about 50 degrees cause southeastward transport toward Cape Cod Bay in a nearshore band along the western side of Massachusetts Bay, and northward into Stellwagen Basin (Figs. 14 and 15). Storms with winds from 50 degrees or greater cause near-bottom flow directly offshore into Stellwagen Basin. Physical or biological vertical mixing of sediments deposited on the seafloor after each storm would bury them in the sediment column and make them less available for resuspension by subsequent storms, efficiently sequestering the silver in the bottom sediments. One hypothesis is that the higher silver concentrations in Cape Cod Bay relative to Stellwagen Basin is attributed to the alongshore transport under winds from the north (Fig. 10), or because some transport pathways to Stellwagen Basin go through Cape Cod Bay. However, the observed distribution of silver in the surficial sediments reflects the cumulative transport caused by a variety of storms with differing wave and wind characteristics and the spatial and temporal history of the discharge of silver into the Massachusetts Bay system over the last 100 years or so. Testing this hypothesis would require a detailed climatology of the historical wave and wind field that is beyond the scope of this paper.

The Northeasters modeled in this paper are some of the largest observed in the 17-year wave record. Storms with weaker winds would drive similar circulation patterns, but the waves, responsible for most of the sediment resuspension, would be weaker and thus would less frequently resuspend sediments in Stellwagen Basin (too deep) and Cape Cod Bay (sheltered from the east). Thus, even small northeast storms would transport sediment along the shallower portions of the transport pathways to depositional sites, but only from shallow water where the waves are strong enough to resuspend sediments.

In the pathways simulations, the deposition of material on the sea floor in some places exhibits a complex spatial pattern. For example, the banding to the east of Cape Cod (Fig. 15) and the variability in sediment deposited along the western shore of Massachusetts Bay (for example Fig. 14, source 1) result from interaction of topography and the phase of the tide at the time the storm waves decrease. These patterns show the potential complexity of sediment transport under realistic condition caused by interactions of topography, tidal current, wave currents and residual flow during periods of resuspension and deposition. Coupled highresolution wave, hydrodynamic, and sediment-transport models provide a mechanism to investigate these patterns and their implications for contaminant transport and fate, sea floor habitat, and long-term change of the sea floor.

\section{Conclusions}

Simulations of suspended sediment transport in Massachusetts Bay have been carried out using a three-dimensional 
numerical model that includes wave, tidal and wind-driven currents. Suspension of sediment in Massachusetts Bay is controlled by waves generated from winds in the Gulf of Maine and transport is accomplished predominately by the wind-driven currents. The orientation of the wind relative to the western shore of Massachusetts Bay determines the residual circulation pattern: winds from the north cause a southerly transport along the coast toward Cape Cod Bay, while winds from the east and southeast cause northerly transport. The simulations show that Northeasters can effectively transport sediments from Boston Harbor and the area offshore of the harbor to the southeast into Cape Cod Bay and offshore into Stellwagen Basin. This transport pattern is consistent with Boston Harbor as the source of silver found in the surficial sediments of Cape Cod Bay and Stellwagen Basin. The model simulations show that some material from these locations is also dispersed into the Gulf of Maine. The simulations were designed to identify transport pathways; assessment of long-term net sediment accumulation in various regions depends on rates and thus requires a realistic simulation of the size of the source.

This paper presents an application of a coupled wave, circulation and sediment-bed model that are new features in ROMS. The simulations were designed to exercise these new capabilities and to explore regional-scale sediment transport under idealized conditions and improve our conceptual understanding of the sediment-transport pathways caused by large storms. The capabilities of the model to simulate multiple sediment sizes was essential to predict the spatial variability of bed material. The results agree qualitatively with geologic observations that average transport over many events and encourages further use and continued assessment of the sediment-transport capabilities of the model.

\section{Acknowledgments}

We gratefully acknowledge support from the USGS Mendenhall Post-Doctoral Research Program for John C. Warner. We thank the developers of ROMS for their collaboration in implementing the sediment transport capabilities in ROMS. Chris Sherwood and Rich Signell provided advice and assistance with the bottom stress calculations under wave and current conditions and Chris Sherwood provided Matlab routines to calculate bottom velocities from the surface-wave spectra and bottom stress based on Madsen (1994). We thank David Schoellhamer and Rich Signell for the insightful reviews of the manuscript. This work was supported by the Massachusetts Water Resources Authority and the U.S. Geological Survey.

\section{Appendix A}

See Tables A1 and A2.

Table A1

Observed and modeled tidal amplitude $(H$, in $\mathrm{cm})$ and phase $\left(G\right.$, in degrees) for $\mathrm{M}_{2}, \mathrm{~N}_{2}, \mathrm{~S}_{2}, \mathrm{O}_{1}$ and $\mathrm{K}_{1}$ tide at selected stations in Massachusetts Bay

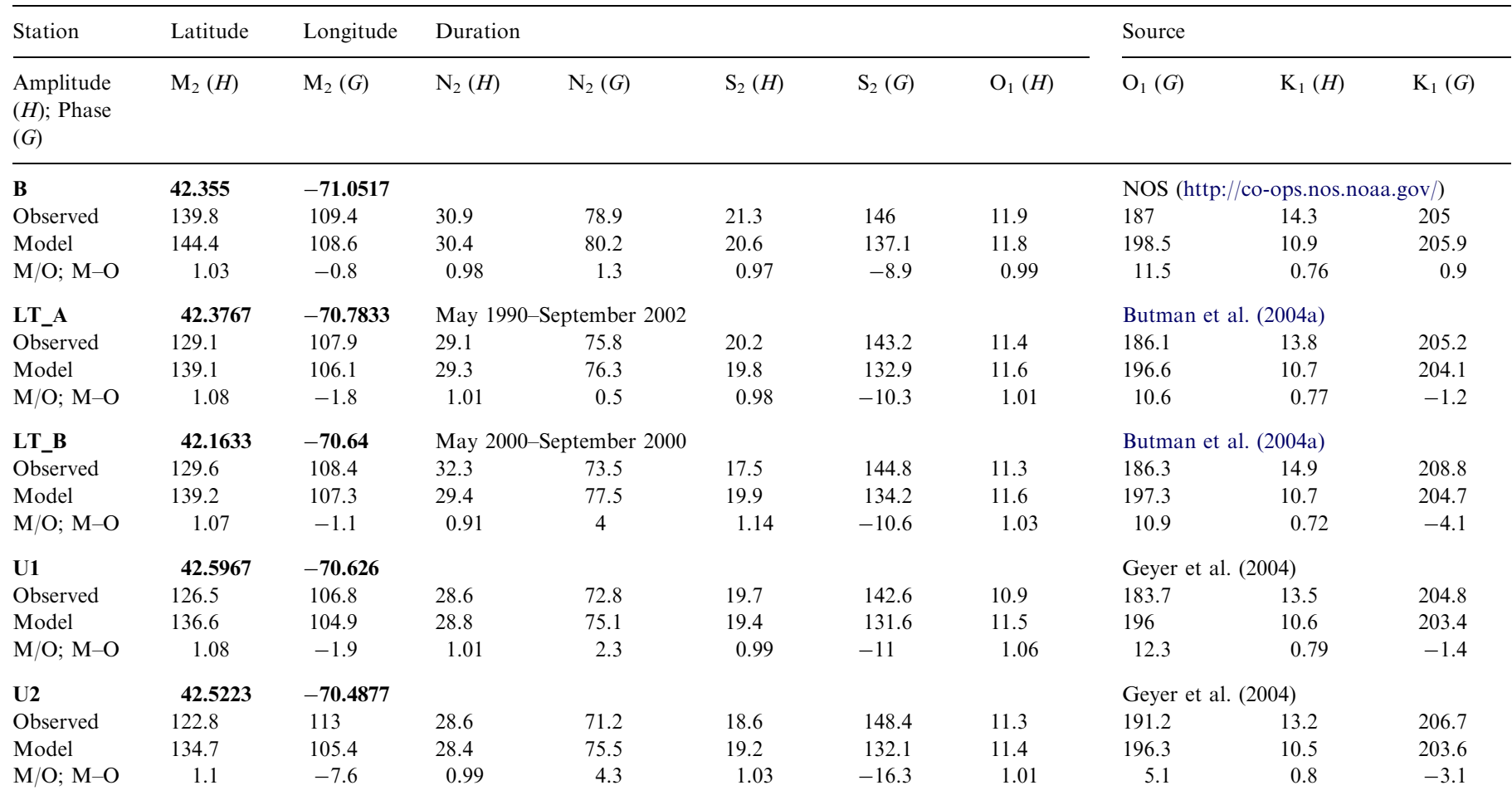


Table A1 (continued)

\begin{tabular}{|c|c|c|c|c|c|c|c|c|c|c|}
\hline \multirow{2}{*}{$\begin{array}{l}\text { Station } \\
\text { Amplitude } \\
(H) \text {; Phase } \\
(G)\end{array}$} & \multirow{2}{*}{$\begin{array}{l}\text { Latitude } \\
\mathrm{M}_{2}(H)\end{array}$} & \multirow{2}{*}{$\begin{array}{l}\text { Longitude } \\
\mathrm{M}_{2}(G)\end{array}$} & \multicolumn{5}{|c|}{ Duration } & \multicolumn{3}{|l|}{ Source } \\
\hline & & & $\mathrm{N}_{2}(H)$ & $\mathrm{N}_{2}(G)$ & $\mathrm{S}_{2}(H)$ & $\mathrm{S}_{2}(G)$ & $\mathrm{O}_{1}(H)$ & $\mathrm{O}_{1}(G)$ & $\mathrm{K}_{1}(H)$ & $\mathrm{K}_{1}(G)$ \\
\hline U3 & 42.3718 & \multicolumn{6}{|l|}{-70.3483} & \multicolumn{3}{|c|}{ Geyer et al. (2004) } \\
\hline Observed & 122.8 & 108.3 & 27.2 & 72.5 & 18.9 & 141.9 & 10.8 & 186.7 & 13.8 & 203.5 \\
\hline Model & 133.7 & 106.6 & 28.2 & 76.9 & 19 & 133.5 & 11.4 & 197 & 10.5 & 204.3 \\
\hline $\mathrm{M} / \mathrm{O} ; \mathrm{M}-\mathrm{O}$ & 1.09 & -1.7 & 1.04 & 4.4 & 1.01 & -8.4 & 1.05 & 10.3 & 0.76 & 0.8 \\
\hline U5 & 42.0617 & \multicolumn{6}{|l|}{-70.2433} & \multicolumn{3}{|c|}{ Geyer et al. (2004) } \\
\hline Observed & 133.3 & 106.5 & 29.9 & 72.3 & 21 & 142.6 & 11.4 & 185.6 & 13.8 & 204.6 \\
\hline Model & 138.9 & 110.8 & 29.3 & 81.1 & 19.8 & 138 & 11.6 & 198.6 & 10.7 & 206.2 \\
\hline $\mathrm{M} / \mathrm{O} ; \mathrm{M}-\mathrm{O}$ & 1.04 & 4.3 & 0.98 & 8.8 & 0.94 & -4.6 & 1.02 & 13 & 0.77 & 1.6 \\
\hline U6 & 42.3552 & \multicolumn{6}{|l|}{-70.4002} & \multicolumn{3}{|c|}{ Geyer et al. (2004) } \\
\hline Observed & 122.2 & 104.4 & 27.9 & 71.7 & 21.9 & 156.3 & 10.7 & 182.4 & 13.4 & 202.7 \\
\hline Model & 134.5 & 106.7 & 28.4 & 76.9 & 19.1 & 133.5 & 11.4 & 197 & 10.5 & 204.4 \\
\hline $\mathrm{M} / \mathrm{O} ; \mathrm{M}-\mathrm{O}$ & 1.1 & 2.3 & 1.02 & 5.2 & 0.87 & -22.8 & 1.07 & 14.6 & 0.78 & 1.7 \\
\hline U6_SBA & 42.355 & -70.4005 & \multicolumn{5}{|c|}{ September 1990-January 1991} & \multicolumn{3}{|c|}{ USGS data archive } \\
\hline Observed & 123.2 & 104.1 & 33.1 & 72.3 & 15.8 & 135.1 & 10.4 & 181 & 16.9 & 197.8 \\
\hline Model & 134.5 & 106.7 & 28.4 & 76.9 & 19.1 & 133.5 & 11.4 & 197 & 10.5 & 204.4 \\
\hline $\mathrm{M} / \mathrm{O} ; \mathrm{M}-\mathrm{O}$ & 1.09 & 2.6 & 0.86 & 4.6 & 1.21 & -1.6 & 1.1 & 16 & 0.62 & 6.6 \\
\hline $\mathrm{CC1}$ & 41.928 & -70.243 & \multicolumn{5}{|c|}{ February 1986-April 1986} & \multicolumn{3}{|c|}{ USGS data archive } \\
\hline Observed & 136.3 & 109.6 & 24 & 85.9 & 29.3 & 155.5 & 11.5 & 185.5 & 11.3 & 185.5 \\
\hline Model & 144 & 110.1 & 30.4 & 80.4 & 20.6 & 137.2 & 11.7 & 198.6 & 10.8 & 206.1 \\
\hline $\mathrm{M} / \mathrm{O} ; \mathrm{M}-\mathrm{O}$ & 1.06 & 0.5 & 1.27 & -5.5 & 0.7 & -18.3 & 1.02 & 13.1 & 0.95 & 20.6 \\
\hline $\mathrm{CC} 2$ & 41.994 & -70.409 & \multicolumn{5}{|c|}{ February 1986-April 1986} & \multicolumn{3}{|c|}{ USGS data archive } \\
\hline Observed & 134.2 & 109.3 & 26.9 & 86.9 & 28.3 & 149.9 & 11.6 & 184.4 & 11.6 & 206.9 \\
\hline Model & 141.5 & 109.1 & 29.8 & 79.4 & 20.2 & 136.2 & 11.6 & 198.1 & 10.7 & 205.7 \\
\hline $\mathrm{M} / \mathrm{O} ; \mathrm{M}-\mathrm{O}$ & 1.05 & -0.2 & 1.11 & -7.5 & 0.72 & -13.7 & 1 & 13.7 & 0.92 & -1.2 \\
\hline MBIWE_B & 42.2881 & -70.4575 & \multicolumn{5}{|c|}{ August 1998-August 1998} & \multicolumn{3}{|c|}{ USGS data archive } \\
\hline Observed & 124 & 109.4 & 23.7 & 88.4 & 18.6 & 154.9 & 11.4 & 182.7 & 13.5 & 223.9 \\
\hline Model & 135.6 & 107.2 & 28.6 & 77.4 & 19.3 & 134 & 11.5 & 197.3 & 10.5 & 204.7 \\
\hline $\mathrm{M} / \mathrm{O} ; \mathrm{M}-\mathrm{O}$ & 1.09 & -2.3 & 1.21 & -11.1 & 1.04 & -20.9 & 1 & 14.6 & 0.78 & -19.3 \\
\hline MBIWE_C & 42.247 & -70.5529 & \multicolumn{5}{|c|}{ August 1998-August 1998} & \multicolumn{3}{|c|}{ USGS data archive } \\
\hline Observed & 126.1 & 109.2 & 24.1 & 88.1 & 19.1 & 155 & 11.5 & 182.7 & 13.7 & 224.4 \\
\hline Model & 137.3 & 107.2 & 29 & 77.4 & 19.6 & 134 & 11.5 & 197.2 & 10.6 & 204.7 \\
\hline $\mathrm{M} / \mathrm{O} ; \mathrm{M}-\mathrm{O}$ & 1.09 & -2.1 & 1.2 & -10.8 & 1.03 & -21 & 1 & 14.5 & 0.78 & -19.7 \\
\hline
\end{tabular}

Station name, location and data source are shown in the header line for each station. $\mathrm{M} / \mathrm{O}$ is the ratio of model amplitude to observation amplitude. $\mathrm{M}-\mathrm{O}$ is model phase minus observation phase (in degrees).

Table A2

Observed and modeled tidal current ellipse major and minor axis, axis orientation, and phase for semidiurnal $\mathrm{M}_{2}$ tide at selected stations in Massachusetts Bay

\begin{tabular}{|c|c|c|c|c|c|c|c|}
\hline Station & $\begin{array}{l}\text { Major axis } \\
\left(\mathrm{cm} \mathrm{s}^{-1}\right)\end{array}$ & $\begin{array}{l}\text { Minor axis } \\
\left(\mathrm{cm} \mathrm{s}^{-1}\right)\end{array}$ & $\begin{array}{l}\text { Axis orientation } \\
\text { (degrees) }\end{array}$ & $\begin{array}{l}\text { Phase } \\
\text { (degrees) }\end{array}$ & $\begin{array}{l}\text { Latitude } \\
(\mathrm{N})\end{array}$ & $\begin{array}{l}\text { Longitude } \\
\text { (W) }\end{array}$ & Duration \\
\hline LT_A & & & & & 42.3767 & -70.7833 & \multirow{4}{*}{ Winters 1990-1997 } \\
\hline Observed (5 mbs) & 10.1 & -0.6 & 74.8 & 201 & & & \\
\hline Model & 10.5 & 0.3 & 71 & 200.8 & & & \\
\hline $\mathrm{M} / \mathrm{O} ; \mathrm{M}-\mathrm{O}$ & 1.04 & -0.54 & -3.7 & -0.2 & & & \\
\hline LT_A & & & & & 42.3767 & -70.7833 & \multirow{4}{*}{ Winters 1990-2002 } \\
\hline Observed (23 mbs) & 9.3 & 0 & 83 & 198 & & & \\
\hline Model & 9.9 & 1 & 71.8 & 197 & & & \\
\hline $\mathrm{M} / \mathrm{O} ; \mathrm{M}-\mathrm{O}$ & 1.07 & -53.22 & -11.1 & -1 & & & \\
\hline LT_B & & & & & 42.1633 & -70.64 & \multirow{4}{*}{ Winters 1997-2001 } \\
\hline Observed ( $5 \mathrm{mbs}$ ) & 7 & 1.2 & 26.7 & 212.7 & & & \\
\hline Model & 8.6 & 2.2 & 14.5 & 219.4 & & & \\
\hline $\mathrm{M} / \mathrm{O} ; \mathrm{M}-\mathrm{O}$ & 1.23 & 1.88 & -12.2 & 6.8 & & & \\
\hline
\end{tabular}


Table A2 (continued)

\begin{tabular}{|c|c|c|c|c|c|c|c|}
\hline Station & $\begin{array}{l}\text { Major axis } \\
\left(\mathrm{cm} \mathrm{s}^{-1}\right)\end{array}$ & $\begin{array}{l}\text { Minor axis } \\
\left(\mathrm{cm} \mathrm{s}^{-1}\right)\end{array}$ & $\begin{array}{l}\text { Axis orientation } \\
\text { (degrees) }\end{array}$ & $\begin{array}{l}\text { Phase } \\
\text { (degrees) }\end{array}$ & $\begin{array}{l}\text { Latitude } \\
(\mathrm{N})\end{array}$ & $\begin{array}{l}\text { Longitude } \\
\text { (W) }\end{array}$ & Duration \\
\hline LT_B & & & & & 42.1633 & -70.64 & \\
\hline Observed (17 mbs) & 5.8 & 2.5 & 33.3 & 199.6 & & & Winters 1997-2001 \\
\hline Model & 8 & 2.7 & 14 & 215.3 & & & \\
\hline $\mathrm{M} / \mathrm{O} ; \mathrm{M}-\mathrm{O}$ & 1.37 & 1.07 & -19.3 & 15.8 & & & \\
\hline U2 & & & & & 42.5223 & -70.4877 & \\
\hline Observed (4 mbs) & 8.3 & 1.5 & 78.8 & 207.6 & & & Winter 1990 \\
\hline Model & 11.7 & 1.8 & 74.3 & 209.8 & & & \\
\hline $\mathrm{M} / \mathrm{O} ; \mathrm{M}-\mathrm{O}$ & 1.42 & 1.15 & -4.5 & 2.2 & & & \\
\hline U3 & & & & & 42.3718 & -70.3483 & \\
\hline Observed (4 mbs) & 29.7 & -1.8 & 66.8 & 209 & & & Winter 1990 \\
\hline Model & 22.3 & -2.6 & 64 & 206.5 & & & \\
\hline $\mathrm{M} / \mathrm{O} ; \mathrm{M}-\mathrm{O}$ & 0.75 & 1.47 & -2.8 & -2.5 & & & \\
\hline U6 & & & & & 42.3552 & -70.4002 & \\
\hline Observed ( $8 \mathrm{mbs}$ ) & 9.7 & 2.6 & 72.6 & 197 & & & Winter 1990 \\
\hline Model & 12.2 & 2.8 & 77.6 & 194.9 & & & \\
\hline $\mathrm{M} / \mathrm{O} ; \mathrm{M}-\mathrm{O}$ & 1.26 & 1.07 & 5 & -2.1 & & & \\
\hline U7 & & & & & 41.967 & -70.333 & \\
\hline Observed (4 mbs) & 13.5 & -0.2 & -4.3 & 198.3 & & & Winter 1990 \\
\hline Model & 19 & 0.3 & -6 & 201.3 & & & \\
\hline $\mathrm{M} / \mathrm{O} ; \mathrm{M}-\mathrm{O}$ & 1.42 & -1.47 & -1.7 & 3 & & & \\
\hline BS & & & & & 42.3867 & -70.9083 & \\
\hline Observed (5 mbs) & 16.1 & 1.4 & 49.7 & 219.8 & & & Winter 1990 \\
\hline Model & 13.4 & 1.4 & 64 & 200.4 & & & \\
\hline $\mathrm{M} / \mathrm{O} ; \mathrm{M}-\mathrm{O}$ & 0.83 & 0.97 & 14.3 & -19.4 & & & \\
\hline MAN & & & & & 41.9317 & -70.46 & \\
\hline Observed (5 mbs) & 11.3 & 0 & -4.9 & 211.1 & & & Winter 1990 \\
\hline Model & 15.3 & 0.3 & -3 & 207.6 & & & \\
\hline $\mathrm{M} / \mathrm{O} ; \mathrm{M}-\mathrm{O}$ & 1.36 & 8.86 & 1.9 & -3.5 & & & \\
\hline $\mathbf{R P}$ & & & & & 42.1067 & -70.2467 & \\
\hline Observed (5 mbs) & 40.8 & 3.3 & 54.3 & 200.2 & & & Winter 1990 \\
\hline Model & 55.2 & -1.2 & 59.6 & 200.1 & & & \\
\hline $\mathrm{M} / \mathrm{O} ; \mathrm{M}-\mathrm{O}$ & 1.35 & -0.35 & 5.3 & -0.1 & & & \\
\hline SC & & & & & 42.2033 & -70.6167 & \\
\hline Observed ( $5 \mathrm{mbs})$ & 7.8 & 1.2 & 45.6 & 202.9 & & & Winter 1990 \\
\hline Model & 9.2 & 2.6 & 29.9 & 213.7 & & & \\
\hline $\mathrm{M} / \mathrm{O} ; \mathrm{M}-\mathrm{O}$ & 1.18 & 2.16 & -15.7 & 10.8 & & & \\
\hline $\mathrm{CC2}$ & & & & & 41.9942 & -70.4093 & $2 / 10 / 1986-3 / 11 / 1986$ \\
\hline Observed (6 mbs) & 16.8 & -0.4 & -4.4 & 205.6 & & & \\
\hline Model & 17.7 & 1 & 4 & 203.7 & & & \\
\hline $\mathrm{M} / \mathrm{O} ; \mathrm{M}-\mathrm{O}$ & 1.06 & -2.55 & 8.4 & -1.9 & & & \\
\hline SB & & & & & 42.2935 & -70.183 & \\
\hline Observed (5 mbs) & 29 & -7.5 & 90.3 & 201.1 & & & $10 / 25 / 1994-4 / 10 / 1995$ \\
\hline Model & 32 & -7.9 & 97.3 & 195.7 & & & \\
\hline $\mathrm{M} / \mathrm{O} ; \mathrm{M}-\mathrm{O}$ & 1.1 & 1.06 & 7.1 & -5.5 & & & \\
\hline SB & & & & & 42.2935 & -70.183 & \\
\hline Observed (31 mbs) & 31.8 & -8 & 96.9 & 195.2 & & & $10 / 25 / 1994-4 / 10 / 1995$ \\
\hline Model & 30.4 & -6.6 & 96.7 & 193.2 & & & \\
\hline $\mathrm{M} / \mathrm{O} ; \mathrm{M}-\mathrm{O}$ & 0.96 & 0.82 & -0.3 & -2 & & & \\
\hline SB & & & & & 42.2935 & -70.183 & \\
\hline Observed (48 mbs) & 26.1 & -3.8 & 93.7 & 184.8 & & & $10 / 25 / 1994-4 / 10 / 1995$ \\
\hline Model & 26.6 & -5 & 95.3 & 190.1 & & & \\
\hline $\mathrm{M} / \mathrm{O} ; \mathrm{M}-\mathrm{O}$ & 1.02 & 1.33 & 1.6 & 5.3 & & & \\
\hline GMA & & & & & 42.5278 & -70.5664 & \\
\hline Observed (2 mbs) & 10.5 & 1.5 & 73.3 & 215.1 & & & Winters 2001-2005 \\
\hline Model & 11.3 & 1.1 & 64 & 218 & & & \\
\hline $\mathrm{M} / \mathrm{O} ; \mathrm{M}-\mathrm{O}$ & 1.08 & 0.73 & -9.2 & 2.9 & & & \\
\hline
\end{tabular}

Station name, location and duration of observations are shown for each observation. Axis orientation is degrees clockwise from north. M/O is the ratio of model to observation for major and minor axis. M-O is model orientation minus observed orientation or model phase minus observed phase. mbs is meters below surface. If the minor axis is negative, the ellipse rotates clockwise. 


\section{References}

Ariathurai, C.R., Arulanandan, K., 1978. Erosion rates of cohesive soils. Journal of the Hydraulics Division, ASCE 104 (2), 279-282.

Beardsley, R.C., Butman, B., Geyer, W.R., Smith, P., 1997. Physical Oceanography of the Gulf of Maine. In: Wallace, G.T., Braasch, E.F. (Eds.), Proceedings of the Gulf of Maine Ecosystem Dynamics Scientific Symposium and Workshop, Regional Association for Research on the Gulf of Maine RARGOM Report 97-1, pp. 39-52.

Blaas, M., Dong, C., Marchesiello, P., McWilliams, J.C., Stolzenbach, K.D., 2007. Sediment transport modeling on Southern California Shelves: a ROMS case study. Continental Shelf Research 27, 832-853.

Booij, N., Ris, R.C., Holthuijsen, L.H., 1999. A third-generation wave model for coastal regions, Part I, model description and validation. Journal of Geophysical Research 104 (C4), 7649-7666.

Bothner, M.H., Casso, M.A., Rendigs, R.R., Lamothe, P.J., 2002. The effect of the new Massachusetts Bay sewage outfall on the concentrations of metals and bacterial spores in nearby bottom and suspended sediments. Marine Pollution Bulletin 44, 1063-1070.

Butman, B., 1976. Hydrography and low frequency currents associated with the spring runoff in Massachusetts Bay. Memoires Societe Royale des Sciences de Liege 6 (10), 247-275.

Butman, B., Bothner, M.H., 1998. Predicting the long-term fate of sediments and contaminants in Massachusetts Bay. U.S. Geological Survey Fact Sheet 172-97. Online at $\langle$ http://pubs.usgs.gov/fs/fs172-97/ $\rangle$.

Butman, B., Noble, M.A., Folger, D.W., 1979. Long-term observations of bottom current and bottom sediment movement on the MidAtlantic continental shelf. Journal of Geophysical Research 84 (C3), $1187-1205$.

Butman, B., Bothner, M.H., Alexander, P.S., Lightsom, F.L., Martini, M.A., Gutierrez, B.T., Strahle, W.S., 2004a. Long-term observations in western Massachusetts Bay offshore of Boston, Massachusetts: Data Report for 1989-2002. USGS Digital Data Series DDS-74, Version 2.0. 1 DVD-ROM. On line at $\langle$ http://pubs.usgs.gov/dds/dds74/ $\rangle$.

Butman, B., Valentine, P.C., Danforth, W.W., Hayes, L., Serrett, L.A., Middleton, T.J., 2004b. Shaded relief, backscatter intensity and sea floor topography of Massachusetts Bay and the Stellwagen Bank region, offshore of Boston, Massachusetts. U.S. Geological Survey Geologic Investigation Map I-2734, scale 1:125,000. 2 sheets. Online at $\langle$ http://pubs.usgs.gov/imap/i2734/〉.

Butman, B., Alexander, P.S., Scotti, A., Beardsley, R.C., Anderson, S.P., 2006. Large internal waves in Massachusetts Bay transport sediments offshore. Continental Shelf Research 26 (17-18), 2029-2049.

Cacchione, D.A., Wiberg, P.L., Lynch, J.F., Irish, J.D., Traykovski, P.A., 1999. Estimates of suspended-sediment flux and bedform activity on the inner portion of Eel River continental shelf. Marine Geology 154 (1-4), 83-97.

Chassignet, E.P., Arango, H.G., Dietrich, D., Ezer, T., Ghil, M., Haidvogel, D.B., Ma, C.-C., Mehra, A., Paiva, A.M., Sirkes, Z., 2000. DAMEE-NAB: the base experiments. Dynamics of Atmospheres and Oceans 32, 155-183.

Chen, C., Beardsley, R.C., Franks, P.J.S., van Keuren, J., 2003. Influence of diurnal heating on stratification and residual circulation of Georges Bank. Journal of Geophysical Research 108 (C11), 8008.

Cookman, J.L., Flemings, P.B., 2001. STORMSED1.0: hydrodynamics and sediment transport in a 2-D, steady-state, wind- and wave-driven coastal circulation model. Computers and Geosciences 27, 647-674.

Crusius, J., Bothner, M.H., Summerfield, C.K., 2004. Bioturbation depths, rates and processes in Mass Bay sediments inferred from modeling of ${ }^{210} \mathrm{~Pb}$ and ${ }^{239+240} \mathrm{Pu}$ profiles. Estuarine Coastal and Shelf Science 61 (4), 643-655.

Davies, A.M., Xing, J., 2002. Processes influencing suspended sediment movement on the Malin-Hebrides shelf. Continental Shelf Research 22, 2081-2113.

Drake, D.E., Cacchione, D.A., 1985. Seasonal variation in sediment transport on the Russian River shelf, California. Continental Shelf Research 4, 495-514.
Fan, Y., Brown, W.S., Yu, Z., 2005. Model simulations of the Gulf of Maine response to storm forcing. Journal of Geophysical Research 110, C04010.

Geyer, W., Gardner, G., Brown, W., Irish, J., Butman, B., Loder, T., Signell, R., 1992. Physical Oceanographic Investigation of Massachusetts and Cape Cod Bays. Technical Report MBP-92-03, Massachusetts Bays Program, US EPA Region I/Massachusetts Coastal Zone Management Office, Boston, MA, 497pp.

Grant, W.D., Madsen, O.S., 1979. Combine wave and current interaction with a rough bottom. Journal of Geophysical Research 84, 1797-1808.

Greenberg, D.A., 1983. Modeling the mean barotropic circulation in the Bay of Fundy and Gulf of Maine. Journal of Physical Oceanography $13,886-904$.

Haidvogel, D.B., Arango, H.G., Hedstrom, K., Beckmann, A., Malanotte-Rizzoli, P., Shchepetkin, A.F., 2000. Model evaluation experiments in the North Atlantic Basin: simulations in nonlinear terrainfollowing coordinates. Dynamics of the Atmosphere and Oceans 32, 239-281.

Harris, C.K., Wiberg, P.L., 1997. Approaches to quantifying long-term continental shelf sediment transport with an example from the Northern California STRESS mid-shelf site. Continental Shelf Research 17 (11), 1389-1418.

Harris, C.K., Wiberg, P.L., 2001. A two-dimensional, time-dependent model of suspended sediment transport and bed reworking for continental shelves. Computers and Geosciences 27 (6), 675-690.

Harris, C.K., Wiberg, P.L., 2002. Across-shelf sediment transport: interactions between suspended sediment and bed sediment. Journal of Geophysical Research 107 (C1).

Harris, C.K., Sherwood, C.R., Signell, R.P., Bever, A., Warner, J.C. Sediment Dispersal in the Northwestern Adriatic Sea. Journal of Geophysical Research, accepted for publication.

He, R., McGillicuddy, D.J., Lynch, D.R., Smith, K.W., Stock, C.A., Manning, J.P., 2005. Data assimilative hindcast of the Gulf of Maine coastal circulation. Journal of Geophysical Research 110, C10011.

Hetland, R.D., Signell, R.P. Modeling coastal current transport in the Gulf of Maine. Deep Sea Research II 52, 2430-2449.

Holt, J.T., James, I.D., 1999. A simulation of the southern North Sea in comparison with measurements from the North Sea Project, Part 2: suspended particulate matter. Continental Shelf Research 19, $1617-1642$.

Jiang, M., Zhou, M., 2003. Massachusetts Bay Hydrodynamic Model and Water Quality Model results in 1998-99: Comparison Report between HydroQual and University of Massachusetts Boston Runs. Report 2003-10, Massachusetts Water Resources Authority, Boston, 42pp. $\langle$ http://www.mwra.state.ma.us/harbor/enquad/pdf/2003-10.pdf $\rangle$.

Kampf, J., Fohrmann, H., 2000. Sediment-driven downslope flow in submarine canyons and channels: three-dimensional numerical experiments. Journal of Physical Research 30, 2302-2319.

Kourafalou, V.H., Savvidis, Y.G., Krestenitis, Y.N., Koutitas, C.G., 2004. Modelling studies on the processes that influence matter transfer on the Gulf of Thermaikos (NW Agean Sea). Continental Shelf Research 24, 203-222.

Larmusiaux, P.F.J., 2001. Evolving the subspace of the three-dimensional multiscale ocean variability: Massachusetts Bay. Journal of Marine Systems 29, 385-422.

Leuttich, R.A., Westerink, J.J., Scheffner, N.W., 1992. ADCIRC: an advanced three-dimensional circulation model for shelves, coasts, and estuaries. Report 1: Theory and Methodology of ADCIRC-2DDI and ADCIRC-3DI. Technical Report DRP-92-6, Coastal Engineering Research Center, US Army Engineer Waterways Experiment Station, Vicksburg, MS, 1992.

Luff, R., Moll, A., 2004. Seasonal dynamics of the North Sea sediments using a three-dimensional coupled sediment-water model system. Continental Shelf Research 24, 1099-1127.

Lynch, D.R., Naimie, C.E., 1993. The $\mathrm{M}_{2}$ tide and its residual on the outer banks of the Gulf of Maine. Journal of Physical Oceanography 23, $2222-2253$. 
Lynch, D.R., Ip, J.T.C., Naimie, C.E., Werner, F.E., 1996. Comprehensive coastal circulation model with application to the Gulf of Maine. Continental Shelf Research 16 (7), 875-906.

Madsen, O.S., 1994. Spectral wave-current bottom boundary layer flows. Coastal Engineering 1994. In: Proceedings of the 24th International Conference, Coastal Engineering Research Council/ASCE, 1994, pp. 384-398.

Mukai, A.Y., Westerink, J.J., Luettich, R.A., 2001. Guidelines for using the Eastcoast 2001 Database of Tidal Constituents within the Western North Atlantic Ocean, Gulf of Mexico and Caribbean Sea. US Army Corps of Engineers Coastal and Hydraulic Engineering Technical Note, pp. IV-XX 〈http://cirp.wes.army.mil/cirp/cetns/wnat/chetn_ wnat_101101a-html.htm $\rangle$.

Pawlowicz, R., Beardsley, B., Lentz, S., 2002. Classical tidal harmonic analysis including error estimates in MATLAB using T_TIDE. Computers and Geosciences 28 (8), 929-937.

Poppe, L.J., Paskevich, V.F., Williams, S.J., Hastings, M.E., Kelly, J.T., Belknap, D.F., Ward, L.G., FitzGerald, D.M., Larsen, P.F., 2003. Surficial Sediment Data from the Gulf of Maine, Georges Bank, and Vicinity: A GIS Compilation. U.S. Geological Survey Open-File Report 03-001〈http://pubs.usgs.gov/of/2003/of03-001/index.htm〉.

Ravizza, G.E., Bothner, M.H., 1996. Osmium isotopes and silver as tracers of anthropogenic metals in sediments from Massachusetts and Cape Cod Bays. Geochimica et Cosmochimica Acta 60, 2753-2763.

Shchepetkin, A.F., McWilliams, J.C., 2005. The Regional Ocean Modeling System: a split-explicit, free-surface, topography-following coordinates ocean model. Ocean Modelling 9 (4), 347-404.

Sherwood, C.R., Carniel, S., Cavaleri, L., Chiggiato, J., Das, H., Doyle, J.D., Harris, C.K., Niedoroda, A.W., Pullen, J., Reed, C.W., Russo, A., Sclavo, M., Signell, R.P., Traykovski, P., Warner, J.C., 2004. Sediment dynamics in the Adriatic Sea investigated with coupled models. Oceanography 17 (4), 46-57.

Signell, R.P., Harris, C.K., 2000. Modeling sand bank formation around tidal headlands. In: Spaulding, M.L., Blumberg, A.F. (Eds.), Estuarine and Coastal Modeling, Sixth International Conference, ASCE, New Orleans, LA, November 3-5, 1999.

Signell, R.P., List, J.H., 1997. Effect of wave-enhanced bottom friction on storm-driven circulation in Massachusetts Bay. Journal of Waterway, Port, Coastal, and Ocean Engineering 123 (5), 233-239.
Signell, R.P., Jenter, H.L., Blumberg, A.F., 1994. Modeling the seasonal circulation in Massachusetts Bay. Estuarine and Coastal Modeling. In: Spaulding, M.L. (Ed.), Proceedings of the Third International Conference. ASCE, New York, NY, pp. 578-590.

Signell, R.P., Jenter, H.L., Blumberg, A.F., 1996. Circulation and effluent dilution modeling in Massachusetts Bay: model implementation, verification, and results. U.S. Geological Survey Open File Report 96-015.

Signell, R.P., Jenter, H.L., Blumberg, A.F., 2000. Predicting the physical effects of relocating Boston's sewage outfall. Estuarine, Coastal, and Shelf Science 50, 59-72.

Umlauf, L., Burchard, H., 2003. A generic length-scale equation for geophysical turbulence models. Journal of Marine Research 61 (2), 235-265.

Warner, J.C., Sherwood, C.R., Arango, H.G., Signell, R.P., 2005. Performance of four turbulence closure models implemented using a generic length scale method. Ocean Modelling 8, 81-113.

Warner, J.C., Sherwood, C.R., Signell, R.P., Harris, C.K., Arango, H.G. Development of a three-dimensional, regional, coupled wave, current, and sediment-transport model. Computers and Geosciences, in press.

Werme, C., Hunt, C.D., 2003. Outfall monitoring overview. Massachusetts Water Resources Authority—Environmental Quality Department Report ENQUAD 2004-13, Massachusetts, Boston, 2004, p. 97.

Wiberg, P.L., Sherwood, C.R. Calculating wave-generated bottom orbital velocities from surface wave parameters. Computers and Geosciences, in press.

Wiberg, P.L., Drake, D.E., Harris, C.K., Noble, M.E., 2002. Sediment transport on the Palos Verdes shelf over seasonal to decadal time scales. Continental Shelf Research 22 (6-7), 987-1004.

Wright, D.G., Greenberg, D.A., Loder, J.W., Smith, P.C., 1986. The steady-state barotropic response of the Gulf of Maine and adjacent regions to surface wind stress. Journal of Physical Oceanography 16, 947-966.

Wright, L., Xu, J., Madsen, O., 1994. Across-shelf benthic transports on the inner shelf of the middle Atlantic bight during the "Halloween storm" of 1991. Marine Geology 118, 61-77.

Zhang, Y., Swift, D.J.P., Fan, S., Niedoroda, A.W., Reed, C.W., 1999. Two-dimensional numerical modeling of storm deposition on the northern California shelf. Marine Geology 154, 155-167. 